\title{
石炭の組織学的検討とその応用についで
}

\author{
木 村 英 雄**.宮 津隆***
}

\section{Petrographic Studies and Its Utilization of Coal for Coke Making}

\author{
Hideo Kimura and Takashi MiYazU
}

\section{1. まえがき}

石炭の組織学的な検討は, 従来地質学者, 基礎的な分 野の研究者などの間では広く行なわれていたが，これが コークス技術者の立場からとりあげられるようになつた のは比較的最近のことである.

とくに, 石炭の主成分であるビトリニットの反射率の 測定が可能になつてからは，これとマセラル分析を組み 合わせて, 少量の試料からコークス化性を推定する方法 が種々検討されるようになつた．この分町では AMMOsov')が Sundgren Test (GOST) 指数を, SCHAPIRO2)3) が Tumbler Test (ASTM) の Stability factor を推定 する方式をそれぞれ報告して以来, 内外で数多くの追 試4)が行なわれている、コークス工業に㧍ける, 組織 学的な手法の応用分野はこれ以外にも種々考えられ, 現 在すでに実用化され始めたものも少なくない。しかしな がら, 石炭の組織, マセラルの命名法, 加熱時における マセシルの挙動など，コークス技術者にとつて必要な知 識でありながら，まだなじみの薄い事項が多いために， この手法の意義が一般に十分理解されているとはいえな いように思われる.

以下, 本資料では第 2 章に組織学的な検討方法の詳細 を，第3 章にこの手法の応用分野の概略を述べることに する.

\section{2. 石炭の組織学的検討}

\section{$2 \cdot 1$ 石宸亡組載成分}

石炭はきわめて永い地質時代を経過する間に，温度， 圧力, 造山運動など種々の環境下で石炭化が進行して生 成されたものである.したがつて，この意味からすれ ば，石炭は天然の有機質の可燃性固体であるといいう る.

石炭の根源植物が，その当時に繁茂した樹木質に由来

* 炤和 46 年 4 月 12 日受付（依頼技術資料）

** 公害資源研究所理博

*** 日本鋼管 (株) 技術研究所工博
することは，疑いのない事実であるが，ただ単に樹木の 幹，枝だけが石炭層を形成するに至つたのではなく，こ の他に枝葉, 枯木, 枮葉など, さらにこれらに付随する 他の夾雑物, 胞子, 菌類, 樹脂, 混入された砂泥, 鉱物 質などが，種々様々な形で集積され，しかも水位の上下 動を伴つた中で，腐朽分解されたるのである．そしてこ うした泥炭地におけるこれらの繰り返しと造山動運との 相対的な関係が，もつとも適切な環境下におかれたその 場所において，長い地質時代を経過する間に，脱水，脱 $\mathrm{CO}_{2}$, 脱 $\mathrm{CH}_{4}$ の反応を伴い, 現在の石炭層を形成した わけである.したがつてその長い遍歴の跡は, 石炭化度 の差異, 組織成分の差異, 性質の不均一性, 不連続性な どの原因ともなつている.

われわれが手にする石炭塊は，特殊なものを除いて， ほとんどが層状の縞状組織を呈していることが認められ るが，それはその石炭が当面した過去の因果関係におけ る結果を示しているにほかならない，肉眼的に均一と思 われる輝炭*の部分でも, 顕微鏡的にみると, さらに微細 な組織成分によつて構成されていることがわかる.すな わち, 石炭の持つ層状構成は, これらの微細な組織成分 が層状に集積されていることに基因するもので，巨視的 には石炭層において，肉眼的，顕微鏡にも，微視的には 電子顕微鏡下において，これを認めることができる.

一般に，石炭化度が異なると，粘結性，流動性，溶剂 抽出率, 粉砕性など, 種々の石炭の性質が異なつてくる ことはよく知られている. しかしながら，こうした微細 な組織成分の含有割合が異なつてくると, 石炭化度が同 一であつても，それらの構造および性質が異なつてく る. 石炭が示すコークス化性についても同様である.

最近わが国における原料炭事情から，輸入原料炭の産 地および銘柄が多種多岥にわたるにつれて, 単に揮発分 あるいは流動性のみでは, その石炭本質の持つコークス 化性を十分に把握することが困難となつてきた. この事 実は，日本炭と外国炭との組織成分上の差異に基づく場 合が多い。たとえば，オーストラリア弱粘炭はほぼ同一

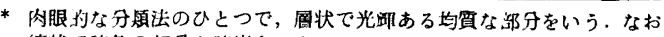
縞状で暗臽の部分支暗炭という。 
石炭化度の日本炭に比して, 揮発分 (d.a.f)*が低い特質 を有するが，その理由は化学的に不活性なイナート系が 多く, これに反して揮発分, 水素含有量の多いェクシニ ット系が比較的少ないことに原因している.

結局，コークス化性の判定を行なう場合に，従来の考 え方に加えて，石炭の組織成分の含有割合について検討 することが必要であることを示している.

以上の関係をごく簡単に考えてみると，石炭の持つ性 質というものは，丁度織物の布地模様を構成する横系と 縦系の関係にあるということができよう.この場合に， 横糸に相当するのは石炭化度であり，これは捙発分ある いは炭素含有量, 流動度, $\mathrm{X}$ 線的な結晶子の大きさなど その他各種試験によつて示される諸物性が含まれる。 方縦系に相当するものが，石炭の組織成分である.すな わち，横系が同一であつても，緹糸である石炭の組織成 分の含有割合によつて, 性質が種々異なつてくることを 示している. 横系と縦糸との相互作用の結果として, そ の石炭が持つ平均的な性状を示すようになることを物語 つている.

石炭のコークス化性を検討する場合に，まず原料炭の 諸性質を知つて配合対策を考える必要があるが，これに はこうした横系と縦系との関係をよく理解し，よく考虑 することが必要である．N. SCHAPIRO らの考え方もま た，石炭化度と組織成分の含有割合に関するデータを基 本的に利用したものであるといえる。

石炭組織の分類法は，国队的にもをた国際的にもいる いろ検討されており，現状では一応の分類基準もでき上 つてはいるが，前述したように天然の有機質固体という ことに加えて, 種々の複雑な不均一性組織を有するとい つた点から，今だに多少の問題点が残されている。しか し筆者の一人 (木村) も関係している国際石炭組織学会 (International Committee for Coal Petrology 略称 ICCP) では, 番議の結果, 1957 年に分類茎準委員会に より分類基準が決定され，同時に国際石炭組織ハンドブ ック 8) (International Handbook of Coal Petrography) として写真とともに公表発刊されている. その後 1963 年にも改訂出版され現在に至つている.

一方日本炭の組織成分については, (財) 石炭総合研究 所内の石炭組織ゼミナールから燃料協会内に石炭組織研 究会が設立され，討諭が重ねられた結果，1956 年に日 本炭のための分類基準 ${ }^{9}$ が作成されている.

石炭を構成する組織的な成分としては, 組織成分と微 細組織成分とがあり，それぞれ細かく分類され命名され ている、またわが国とヨーロッパでは，ほぼ同一で IC CP の命名法を採用しているが，アメリカの一部におい ては, 石炭の組織成分を次のように4 種類に分類してい るところもある.

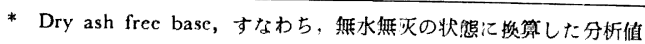

1) アンスラキシロン (Anthraxylon)

2) 透明アトリタス (Translucent attritus)

3 ) 不透明アトリタス (Opaque attritus)

4) フゼーン (Fusain)

アメリカのこの考方方は, 石炭に対して植物学的な手 法を取り入れたためで，薄片法による透過光線下の組織 を対象にしている.

最近では, U. S. Steel 社の N. SCHAPIRo を始めと して，コークス工業に関連する関係名社では，いずれも ヨーロッパ風の命名法を採用している. したがつて, こ こでは上記アメリカの 4 分類関係の考え方は，ふれない ことにする.

\section{$2 \cdot 2$ 石炭の微細組織成分 (マセラル) ${ }^{10)}$}

石炭は植物質をその根源とする有機質の固体であるの で, 組織的にみると微細な組織成分によつて構成されて いる.

崖石学においては，岩石 (Rock)はミネラル (Mineral) から構成されているのと同様に, 石炭組織学ではこれに 対応させて微細組織成分またはマセラル(Maceral) とい う・たとえば, 花崗岩という岩石は石英, 長石, 雲母な どのミネラルによつて構成されているように, 石炭組織 成分*の一つであるクラリットはビトリニット, エクジニ ットなどの微細組織成分またはマセラルによつて構成さ れているということである.

微細組織成分であるマセラルには，10種類もあるが， かならず語尾に“一ニット”(一nite) をつけて分類され ている.

国際石炭組織学会では, 顕微鏡下の性質が類似してい るマセラルを一つのグループにまとめて表示する方法を とつている、すなわち、マセラルおよびマセラル・グル ープについて示すと表1のとおりである.

これらのマセラルは, 石炭を形成するに至つた根源植 物のうちのいずれかの部分が，石炭化にさいしその形態 を残存したものである。一般に，植物組織中には分解に 対して抵抗の強いものと弱いものとがある.すなわち， 原形質、葉緑素, セルローズ, リグニンなどは分解され やすいが，角皮，胞子，樹脂などは分解され難いことを 示している，表 1 は，石炭組織自身の性質を植物を主体 として考えた分類であつて，実際に工業的利用を図る場 合には，それぞれの性状を考虑に入れる必要がある.

コークス工業においてコークス化性を考虑すると，組 織中には䡉化溶融時に溶融する成分と溶融しない成分と がある・ビトリニットおよびェクジニット・グループは いずれも溶融成分で，イナーチニット・グループは不溶 融成分である，溶融成分はもちろん，石炭化度によつて

* 石炭組徽成分には，ピトリット，クラリット，ドリット，フシットか よびビトリイナーチット, ドロクラリット,クラロドリットの7種類 がある. 前 2 者は肉腿的な鄰炭に,ドリットは暗炭に, フシットは木

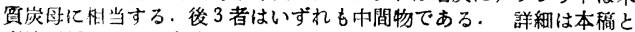
直接阴係ないので省略する。語尾に“ーリット”(一rite)をつけて分類 される. 
表 1 マセラルとマセラル・グループ (1963 年)

\begin{tabular}{|c|c|c|}
\hline マセラル (Maceral) & マセラル・グループ (Maceral group) & 略称 (Symbol) \\
\hline $\begin{array}{l}\text { 1. コリニット (Collinite) } \\
\text { 2. テリニット (Telinite) } \\
\text { 3. (デグラディニット Degradinite) }\end{array}$ & ビトリニット (Vitrinite) & V \\
\hline $\begin{array}{l}\text { 4. スポリニット (Sporinite) } \\
\text { 5. クチニット (Cutinite) } \\
\text { 6. フルギニット (Alginite) } \\
\text { 7. レジニット (Resinite) }\end{array}$ & $\left\{\begin{array}{l}\text { エクジニットまたはリプチニット } \\
\text { (Exinite or Liptinite) }\end{array}\right.$ & $\mathrm{E}$ \\
\hline 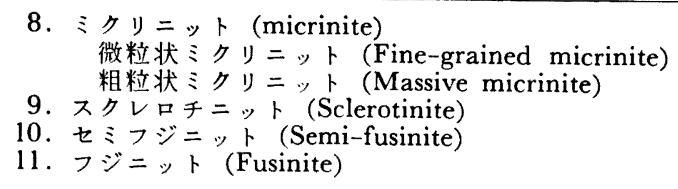 & イナーチニット (Inertinite) & I \\
\hline
\end{tabular}

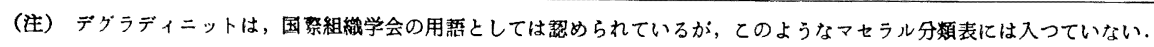

異なるということは当然であるたとえば，ビトリニッ 卜は溶融成分の代表的マセラルであるが，覀炭，褐炭の 一部および無煙炭のそれは，いずれも溶融しない，これ に対してィナーチニット・グループは, 石炭化度には関 係なくいずれも不溶融成分である.

次にこれらのマセラルおよびマセラル・グループにつ いて，写真を参考にしながら概説して子る.

1) ビトリニット・グループ(Vitrinite group)

主として植物の木質部に由来している.

植物の細胞組織を残存しているものをテリニット, 細 胞組織が認められないものをコリニットというが、いず れもビトリニット・グループに属する（写真 $1 ， 2$ ）。 テ リニットは，一般に石炭化度の低い石炭汪ど多く認めら れる傾向がある.

他のマセラルに比較してより均質で，石炭を構成する 有機質の主要部分を占めている。したがつて，ほとんど すべての石炭中に存在する. 石炭の化学槥造や諸性質に ついて研究する場合に, 比重分離によつてビトリニット のみを選別分雖して，これを対象とするのむこのためで ある.

石炭化度の差異によつて異なるが，反射光線下では淡 黄色 (乾式), 灰白色 (油浸), 透過光線下では黄褐色〜赤褐 色にみえる. 一般に石炭化度が高くなると，反射率が増 大するためにより明るくなり，より淡色となつてくる．

デグラディニット (Degradinite) は, 国際石炭組織学 会のマセラル・グループとしては入つていないが，当時 わが国のこの方面の研究者の集りである石炭組織研究会 では種々の検討を重ねた結果, 日本炭の特徵を示すマセ ラルの一つとして提案したものである. 現在, 国際石炭 組織ハンドブック 1963 年改行版には，このデグラディ ニットの名称は出ているが, ビトリニット・グループに 入れるべき性格のものである.

デグラディニットは，ビトリニットと同様のものであ
るが，植物の木質部が微 細に崩壊したものに由来する (写真15). テリニットやコリニットとは違つた腐食化過 程あるいは堆積環境下にあつたものと考えられ，きわめ て微紐なものの集まりである，その色調は，ビトリニッ トに類似しているが，一般に共存するビトリニットより は暗色である.

結局，デグラディニットは，日本炭のドリット*の基 質をなす特徴的なもので，日本炭を理解する上に必要な マセラルであるといえる.

この基本的な概念は，ドリットを構成する他のマセラ ル類は微小なものの集をりであるから，テリニットやコ リニットのように樹木の木質部が石炭化したものは均質 でしかも比較的幅のある層状体あるいは枝状，带状とな るはずで,これらの中には容易に入りえないであろうし， 少なくとも微細に崩壊したものと共存しうる可能性の方 が高いであろらと考えられることから出発している.

このように微細に崩壞したという状態は, 薄片法によ る透過光線下でよく識別することができる.

なお日本炭ばかりではなく，外国炭においても，デグ ラディニットといわれるべき部分をクラリット**あるい はドリット中に認めることができるので, 日本類のみの 問題ではないようにも思われる.

ちなみに，このデグラディニットを含めると，石炭を 構成する微細組織成分であるマセラルは全部で 11 種類 あることになる。

2 ) エクジニット・グループ(Exinite group)

エクシニット・グループはをた別にリプチニット・グ ループ(Liptinite group)ともいわれる. このグループの マセラルとしては, クチニット, スポリニット, アルギ ニットおよびレジニットの 4 種類がある.

* イナーチニットナェクジニットが 95\% 以上あるものをいう. 日本 炭の場合は，デグラディニットが基質を椾成している。

**ビトリニット+エクシニットが $95 \%$ 以上あるものをいう. 


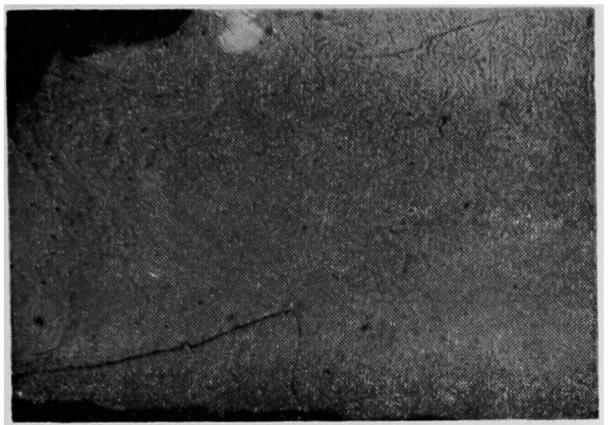

写真 1 ピトリニット(テリニット)高松炭 $(\times 200$ 油浸 $)(6 / 7)$

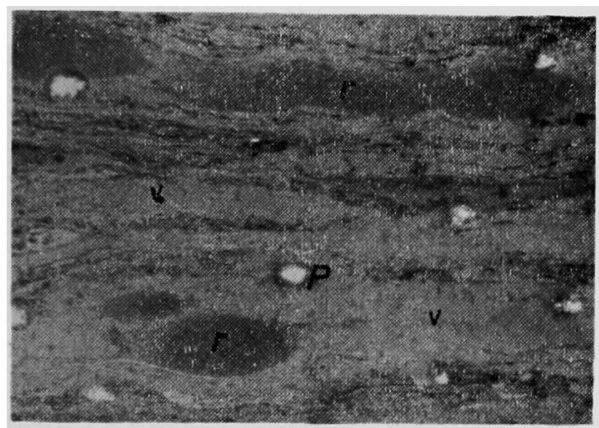

写真 3 レジニット $(\mathrm{r})$ と黄鉄鉱 $(\mathrm{p})$ 小さな黒い 点は粘土鉱物, 常盤湯本炭 ( $\times 200$ 、油浸 $)(6 / / 7)$

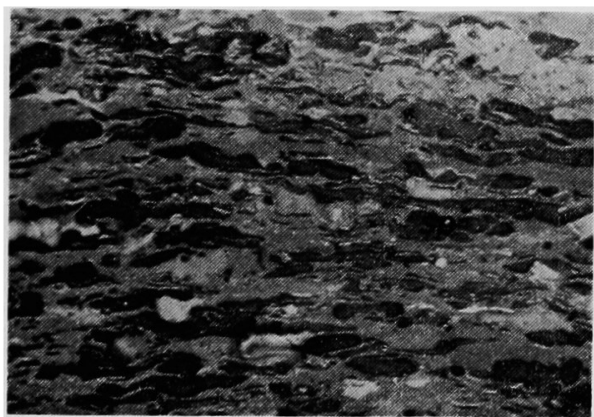

写真 5 スポリニット (sp) リンコ炭 (×200 油浸) $(6 / 7)$

クチニットは，植物の葉，小枝などの角皮に由来する （写真 4). 線状または帯状で，しばしば特徵的な鋸萪状 を呈するものがある. 米国炭, ソ連炭中には, 大部分が クチニットのみによつて構成されている石炭があり, 紙 状炭ともいわれている.

スポリニットは, 胞子, 花粉, 種子に由来し, それら の原形をたは変形と認められるもので, やや扁平な微粒

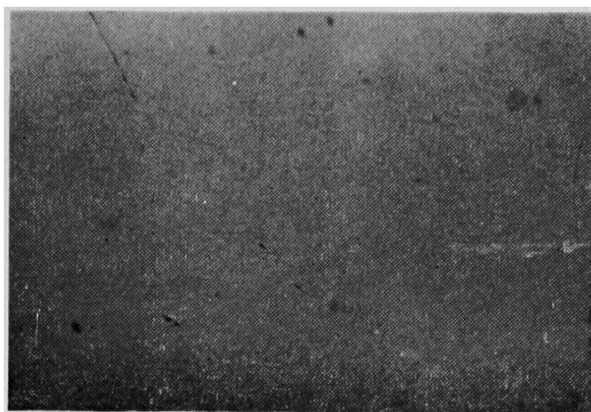

写真 2 ビトリニット (V) (コリニット)イット マン宸（×2010 油浸） $(6 / 7)$

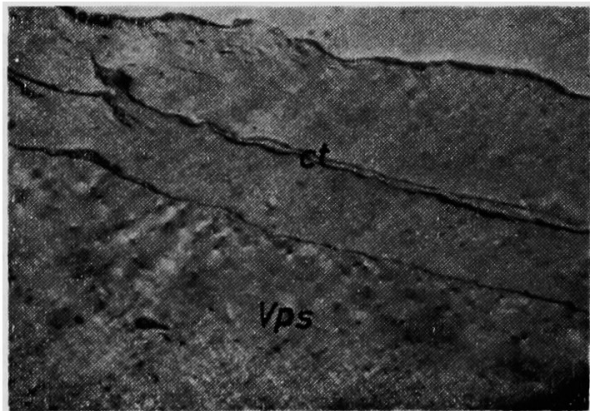

写真 4 上部の細長い三本の線状のものがク チニット (ct). 下部はシニードピト リニット (Vps). リンコ炭 $(\times 200$ 油浸) $(6 / 7)$

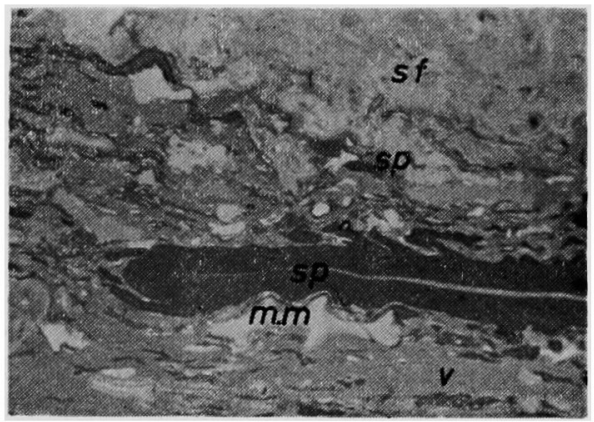

写真 6 マクロスポリニット（右下方の喑灰 色の長いもの).上部はせミフジニッ ト (sf). デービスプレンド炭 (×200 油浸) $(6 / 7)$

である(写真 5)，ときには大胞子に由来する大型のスポ リニットを認めることがかるが(写真 6$)$, 日本炭の場合 はほとんどが微粒である(写真15)，米国炭中には，比較 的多量にスポリニットを含有する石炭がある.

アルギニットは，水藻頑に由来する．日本炭中にはま だ発見されていない.ヨーロッパなどにおいてみられる 腐泥炭中には多く認められている。したがつて，輸入原 


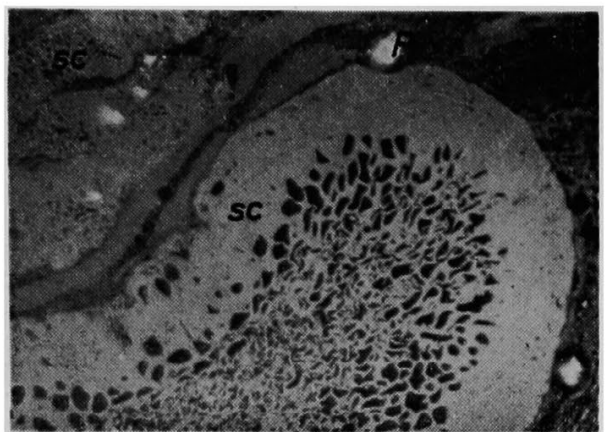

写真 7 スクレロチニット (sc) 常盤楊本炭 $(\times 200$ 油浸) $(6 / 7)$

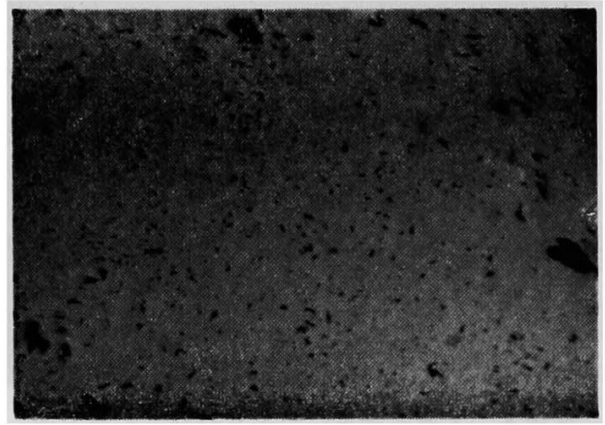

写真 9 セミフジニット(sf)モーラ炭 ( $\times 200$ 油浸) $(6 / 7)$

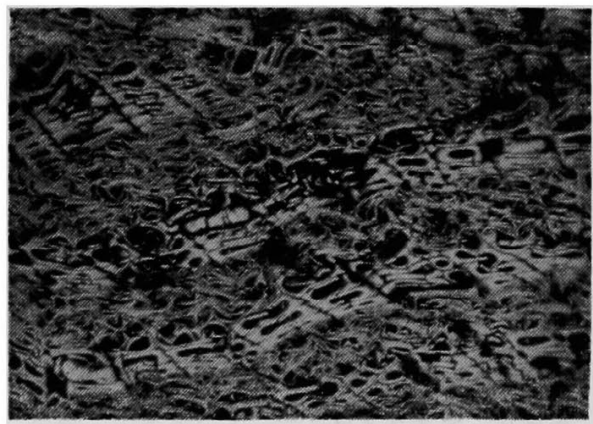

写真11フジニット常盤湯本炭 ( $\times 200$ 油浸) $(6 / 7)$

料炭中でもまだ認められていないので, 現在のところ, そう問題にはならないマセラルである.

レジニットは，樹脂質に由来するもので，一般に長円 状を呈することが多い(写真 3). .レジニットは，ときに はテリニットの細胞腔を埋めて認められる場合, クチニ ットの存在する付近に特殊な形をとつて認められる場合 などがある・

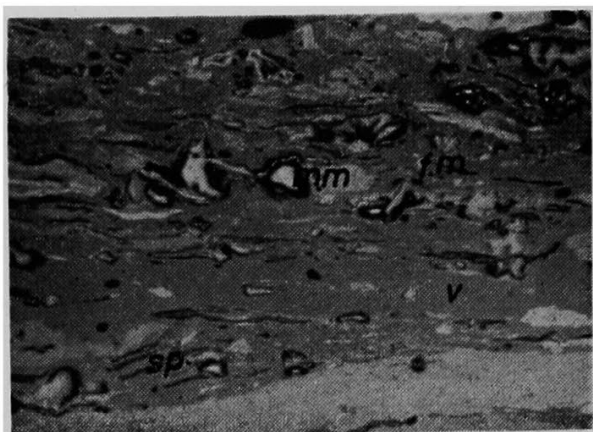

写真 8 ミクリニット(微粒状 $(\mathrm{fm})$ のむのと 粗粒状 (mm)のものがある) モーラ炭 ( $\times 200$ 油浸) $(6 / 7)$

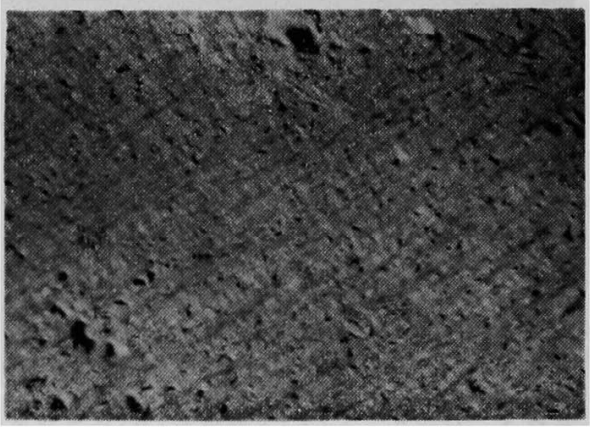

写真 10 セミフジニット（写真 9 と同一個所で クロズニコルにした場合, 偏光組織が よく見える）モ一ラ岸 $(\times 200$ 油浸) $(6 / 7)$

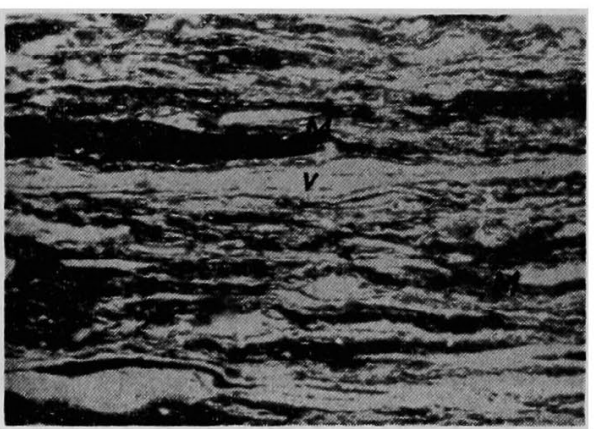

写真 12 粘土鉱物 (M)イットマン炭 (×200 油浸) $(6 / 7)$

石炭化度によつて異なるが，一般に反射光線下では淡 灰色〜黄赤色(乾式), 喑灰色〜暗黑色 (油浸)にみえる. したがつて, 共存するビトリニットよりは暗色を呈す る.

以上のように，エクジニット・グループは腐食化，石 炭化の過程で, 分解に対する抵抗が強いために, 種々の 形で石炭中に残存したもので，その特徵的な形態と色調 


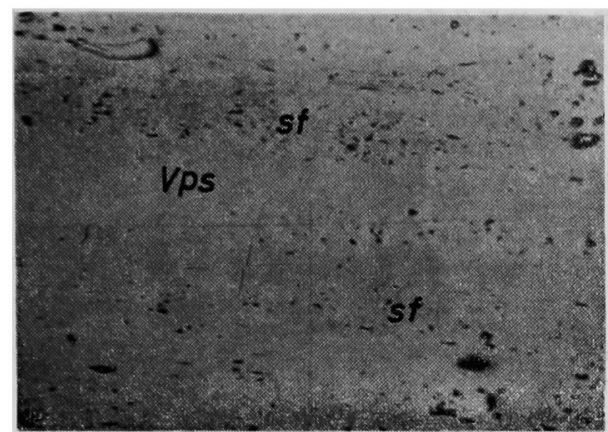

写真13 シュードビトリニット (Vps) とセミフジ ニット (sf) ビートリス炭 $(\times 200$ 油浸) $(6 / 7)$

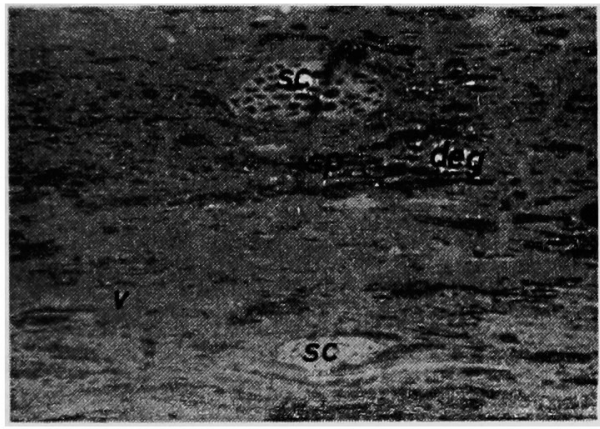

写真 15 ビトリニット(v), デグラディニット (deg), スポリニット (sp)多室のスクレ 口チニット (sc) も見られる. 常盤湯本炭 $(\times 200$ 油浸 $)(6 / 7)$

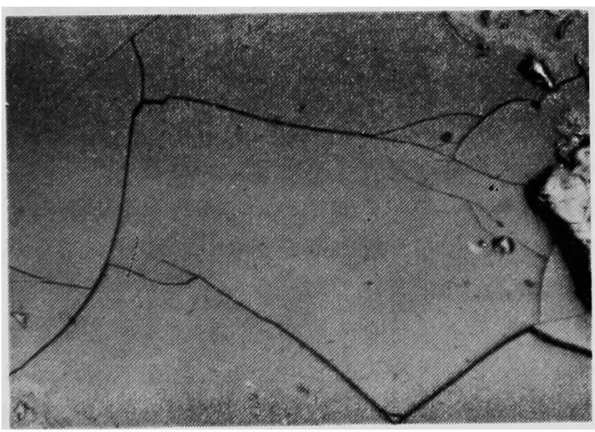

写真 17 風化重裂 イットマン炭 ( $\times 200$ 油浸) $(6 / 7)$

とによつて，他のマセラルとは容易に区別しうるもので ある・

日本炭のドリット中には, エクジニットのうちとくに スポリニットを主とするものが, 比較的多いという特徵

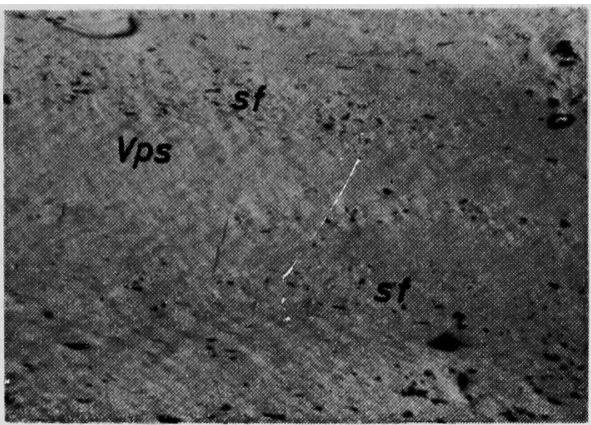

写真14 シュードビトリニットとセミフジニッ ト（写真 13 と同一個所でクロスニコ ルにした場合, シュードビトリニット の結晶した組織がよく見える.) ピートリス炭（×200 油浸） $(6 / 7)$

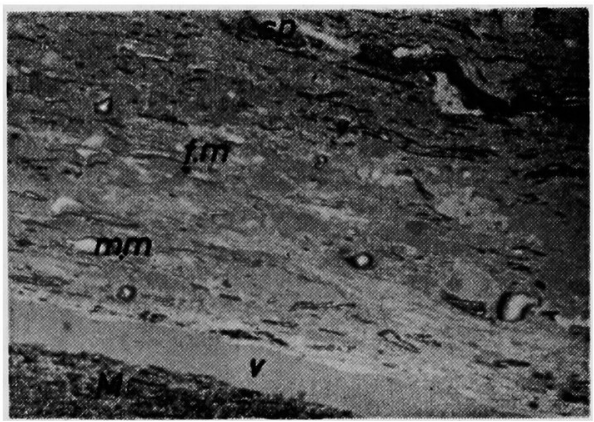

写真16ミクリニット（微粒状 ( $\mathrm{fm})$, 粗粒状 $(\mathrm{mm}))$, スポリニット (sp), 左下方に ビトリニット（v)の層と夾んで粘土鉱 物がある.デービスブレンド炭 $(\times 200$ 油浸 $)(6 / 7)$

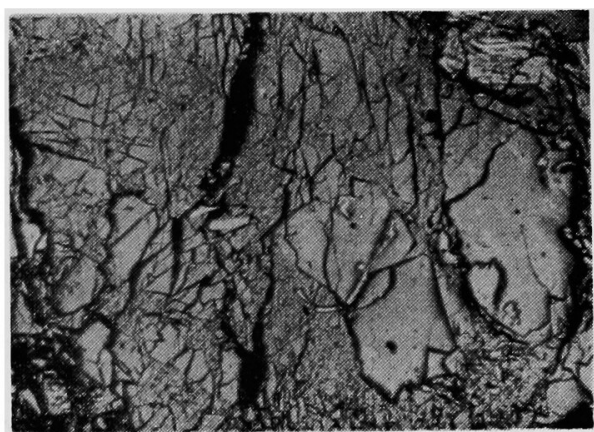

写真 18 風化䈀 イットマン炭 ( $\times 200$ 油浸) $(6 / 7)$

がある

エクジニット・グループは, 石炭化度の増大に伴つて 次第に淡色となり, 次第に共存するビトリニットとの区 別が困難となり，ビトリニット類似物質となつてくる. 
愉入原料炭の場合, 一般に低揮発分強粘結炭領域では エクジニット・グループの含有割合が，きわめて少ない かほとんどないので，このようなビトリニット化現象が 起こつた結果と推定される.

3) イナーチニット・グループ(Inertinite group)

このグループにはミクリニット，スクレロチニット， セミフジニットおよびフジニットの 4 種類がある. ミク リニットには粒状ミクリニットと粗粒状ミクリニットと がある、しかしコークス工業においては，別にこれを区 別して考える必要はない.

イナーチニットという言葉が示すように, 化学的に不 活性なもので斿る。したがつて，これが必要以上に多い とコークス化性を覀くすることになる．ただし N. ScHAPIRO らの考光方では，七ミフジニットのみは，この $2 / 3$ を化学的に不活性なものとしており, 残りの $1 / 3$ を 活性成分として取り扱つている. この原因は, セミフジ ニットはフジニットからビトリニットへの移化過程にあ ることに注目したためである。

ミクリニットは, その名が示すとおりに，微細な微粒 状あるいは粗椟状のむので（写真 6,8，16），それがな にから由来されたかは, ほとんど不明である.しかし， その色調, 形態, 付近に分布する他のマセラルなどから 推定して, スクレロチニット, セミフシニット, フジニ ットなどが，微細に崩壊したものであると思われる。そ の他エクジニットの一部あるいはビトリニットが，腐食 化, 石炭化に際して, 特殊な条件下におかれたために生 成されたとする考え方もある。

スクレロチニットは, 菌類に由来する.1室のドーナ ツ型をしたものから 2 室, 3 室, 4 室さらに多室の蜂の 巣状をした菌核がある(写真 7,15). この他に菌系, 長 円形ないし不規則な形状をした網状体のものもある. 一 般に, 日本炭中のものは外国炭に認められるスクレロチ ニットとは異なつており, 外国炭の方が複雑な形状を示 すものが多い。

セミフジニットは, フジニットとビトリニットとの中 間的なもので, 脈状あるいはレンズ状で，ときには破砕 された形で存在する(写真 $6,9 ， 10)$. ビトリニットと フジニットとの移化過程にある状態で認められる場合も ある. 一般に, 植物の細胞組織が認められる.

フジニットは，植物質の木質部に由来する. しかし共 存するビトリニットとは，その組織状態がまつたく異な つているのが特徵的である. 木炭状の細胞組織が認めら れるものと，これらの破砕された組織を呈するものとが ある(写真11)。交た券巻状の特徽的な構造すなわち弧状 構造 (Bogen structure)を示すものむある.

これらのイナーチニットは，いずれも反射光線下では 淡白色～淡灰色 (乾式), 灰白〜白色 (油浸)にみ元, 透過 光線下では暗色〜不透明にみえる.したがつて，その特 徵的な形態と白色系の色調のゆえに, 他のビトリニット
あるいは黒色系のエクジニット・グループとの区別が容 易である.

ミクリニットを始めとしてセミフシニット，フシニッ 卜は, 日本炭中には比較的少ない特徴がある. 日本炭の 場合のイナーチニットとしては，ほとんどスクレロチニ ットより構成されることが多い.

これに反して, 輸入原料炭は, 一般にイナーチニット ・グループの存在が認められる. 普通 19〜25\% 程度の 含有割合を示すが，ときには 40〜50\% をるいは一部の コールクリフ炭にみられるごとく $50 \%$ 以上にも達する ものがある。

イナーチニットをとくに多く含有する石炭は, オース トラリア, インド, 南アフリカおよび南アメリカの諸地 域である.すなわち当時は陸続きないしは同一気候であ つたと考えられているいわゆるゴンドワナ作用 (Gondwana formation) の及んだ地域に産出するものである. この頃は比較的に乾燥した気候であつたといわれている ので，この辺の事情が共通して関係したものと思われ る・ちなみに, 北アメリカおよびョーロッパの石炭紀時 代は，逆に温暖で多湿な気候であつたといわれており， 明らかに植物質の差異および植物質の腐朽分解過程すな わち腐食化過程の差異などが認められているので，これ らの影響があつたものと考えられる。

したがつて，コンドワナ作用の及えだ地域からの輸入 原料炭は，イナーチニット・グループの量的割合および その形態について，さらには関連するコークス化性への 影響についても，十分に考虑する必要があるといわなけ ればならない。

\section{4 ）鉱物質}

石炭中にはかならず若干の鉱物質が含有されている. これには根源植物質自身に由来するものと腐食化, 石炭 化の過程で石炭中に混入あるいは随伴したものとがあ る.

輸入原料炭では，一般にその堆積規模の問題もあつて 鉱物質の存在割合が少ない，石炭灰の分析值をみても， 輸入炭のそれは数\%にすぎなが，日本炭では一般に10 \%以上はあるのが普通である。これを $10 \%$ 以下にする ためには，比重選別か選炭をすれば可能であるが，その 際の歩留が問題となつてくる.

日本炭のドリット中には，鉱物質とエクジニット，デ グラディニットとが細かく共存している場合が多い（写 真 $3 ， 15)$. この鉱物質は主に微細な粘土鉱物であるが, 顕微鏡下には乾式, 油浸ともに黑色の微粒となつて認め られる. 最近, 輸入原料炭中にも鉱物質の含有割合の高 いものがみられるが，石炭を取り扱う場合には，どうし ても鉱物質の存在を除外して考えるわけにはいかない.

鉱物質としては，この粘土鉱物が主であるが（写真 3 12, 15，16), この他に硫化鉄（肎真 $3 ， 7$ ), 炭酸塩, 石英なご種々のものがある. 
結局, 石炭は組織学的について, 微細な組織成分であ, る 3 種のマセラル・グループと鉱物質とから構成されて いるということになる.

ちなみに，これを別の見方をすれば次のようにもいえ ることになる.すなわち, 反射光線下の問題としては, 基質がビトリニット(あるいはデグラディニット)でおお われているところに黒つぽいものが多いが，白つ添いも のが多いかという問題になる．黑つぽいものが多い場合 にはビトリニット+エクジニット系であり，白つぽいも のが多い場合にはビトリニット+イナーチニット采であ るといえる.また透過光線下の問題とすれば，光を通す ものと通さないものとの違いとなる，すなわち前者では ビトリニット系か, ビトリニット十エクジニット系であ り, 後者ではイナーチニット系であるということができ る.もちろえ，鉱物質が共存する場合にはこの影響が入 つてくる.

要するに，日本炭では，基質がビトリニットかデグラ ディニットかの問題であり, 反射光線下では白色系の1 ナーチニットが少ないかわりに，黑色系のエクシシニト および鉱物質が混在していることになるわけで, 輸入原 料炭では，一般に鉱物質は少ないが，イナーチニットが 多く混在しているという型になつている.

マセラルの一般性状については，世界各国においてそ れぞれの立場から種々の研究が進められているが，中で もC. KRÖGER ${ }^{11}$ が,ザール炭についてもつとも系統的な 研究を行なつている.いくつかの例について示すと次の とおりである. 揮発分は, 石炭化度が上昇するととも に, いずれのマセラルでも減少するが, 同一石炭化度の ところでは，一般にエクジニットがもつとも多く，エク ジニット>ビトリニット>イナーチニットの順となつて いる. この傾向は水素含有量についても同様である. 一 方, 炭素含有量についてみると, 一般にイナーチニット がもつとも高く, イナーチニット>エクジニットフビト リニットの順となつている. またディラトメーターによ る膨張収縮曲線は, ビトリニットとくにエクジニットは 著しい膨張収縮曲線を描くこと, その挙動は石炭化度に よつてそれぞれ異なること，イナーチニットは石炭化度 に関倸なくいずれも収縮曲線のみを描くことなどが明ら かにされている.これらの事実は，N.SCHAPIROらが， ビトリニットおよびェクジニットを活性成分といい，イ ナーチニットを不活性成分という一つの根拠ともなつて いる.

なお，流動性についても同様の傾向が認められており， これらに関しては $B$. Alpern $^{12)}, H$. HoffMANN ら ${ }^{13)}$ の報告がある.

このような観点から, 最近 $R . R$. THOMPSON ${ }^{14)}$ はコ 一クス化性を考慮してマセラルを表 2 のように分類して いる. 要するに, 反射率をも含めて, 活性成分, 不活性 成分および中間成分として半不活性成分の 3 成分に分類
表 2 コークス化性を考虑したマセラルの分類 (R. R. Thompson 5)

1. 活性成分 (Reactives)……射㡭が低い

ビトリノイド (Vitrinoid)

エクジノイド (Exinoid)

レジノイド (Resinoid)

2. 半不活性成分 (Semi-inerts) ……射率が中間的

セミフジノイド (Semi-fusinoid)

セミミクリノイド (Semi-micrinoid)

偽似ピトリノイド (Pseudo-vitrinoid)

3. 不活性成分 (Inerts) ……射率が高い

フジノイド (Fusinoid)

ミクリノイド (micrinoid)

マクリノイド (macrinoid)

（注）反射率の此較は，それぞれ共存した場合の比较である。石炭化度 が高くなれば反射率も次第に高くなつていく。

している、また従来の“一ニット”で終るものをマセラ ル・シリーズ (Maceral series) といい, “一ノイド”( noid)で終るものをマセラル・グループ(Maceral group) と区別している。これは前述したように，たとえばビト リニットはどの石炭化度の石炭中にも存在するわけであ るから，これらは共通させてマセラル・シリーズとして 考えるのに対して, ビトリノィドというのは石炭化度が 中程度の石炭, すなわち通常のコークス用原料炭に属す る瀝青炭中に存在するビトリニットに対して名付けたも のである.したがつて, 亜炭, 褐炭クラスの非粘結炭に 対してはキシリノイド(Xylinoid), 制煙炭クラスに対し てはアンスリノイド(Anthrinoid) といって基本的に区別 している.しかしながらコークス用原料炭を対象として いるので，実際にはビトリノィドもビトリニットと同一 視して取り扱つてもなんら差支えないといえる. 将来一 般炭，無煙炭などの配合割合が增加した時点においては 考虑されなければならない。

一方, 中間的な半不活性成分のうちの偽似ビトリノィ ドは, Bethlehem Steel で始めて使用されたもので，以 前は活性成分として考えられていたが，コークス化過程 で，事実上半不活性的にまたは不活性的性質を示すので 分けて考元られるようになつた. 初期には交代ビトリ， イドといわれていたものである.

マクリノィドは, 詳細な説明はないが微粒状ミクリ二 ットをミクリノイドというのに対して, 粗粒状ミクリニ ットをいつているものと思われる。 またスクレロチニッ 卜もこの中に含めて考えているものと思われる.

以上のように考えることによつて，コークス化性をよ り実際の強度に近からしぬようとする努力が払われてい ると解釈しうる. いずれにしても，マセラルの含有割合 とその反射率を測定することによつて, その石炭の石炭 化度と組織成分的な位置づけを，とりもなおさず横系と 


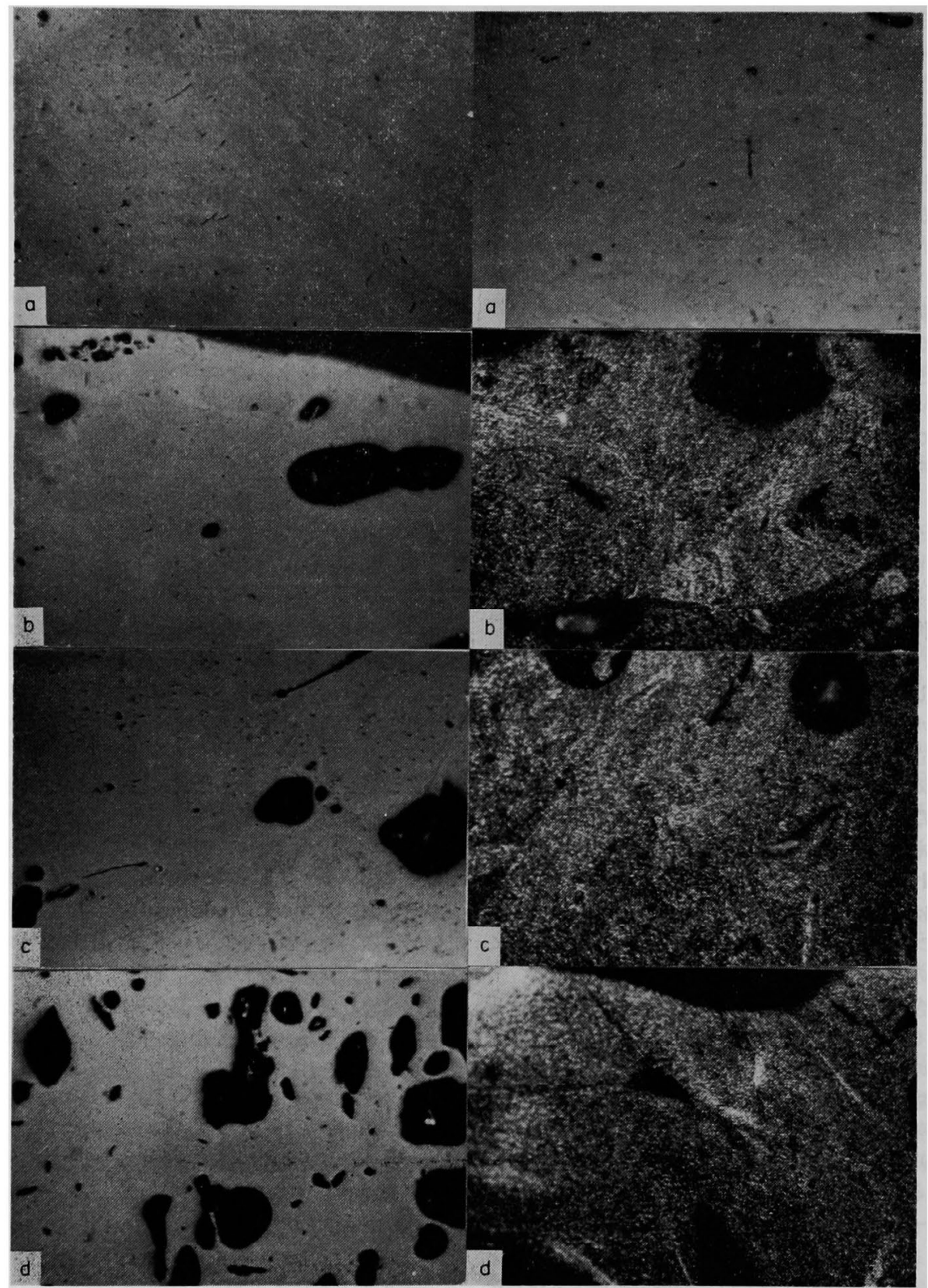

美唄炭 $(C=81 \cdot 1 \%, V M=47 \cdot 2 \%$, daf $)$

(a) $400^{\circ} \mathrm{C}$, (b) $450^{\circ} \mathrm{C}, \quad$ (c) $500^{\circ} \mathrm{C}, \quad$ (d) $900^{\circ} \mathrm{C}$

写真19 乾留の初期段階においてみられるビトリニットの等方性棈造（美唄炭, 左側）と粒状モザ イク椿造（夕張炭，右側），(反射偏光 $\times 150$ )

縦糸との関係を明らかにすることが，コークス強度推定 上必要であるといえる.

ちなみに，ビトリニット，ビトリノイドで示されるマ セラル・シリーズとマセラル・グループの考方方は, 最
近 ASTM の一つの規格案 (ASTM-D 2796(1969)) と して, 次に述ベるマセラル分析法, 反射率測定方法とと もに規格化されつつある。 


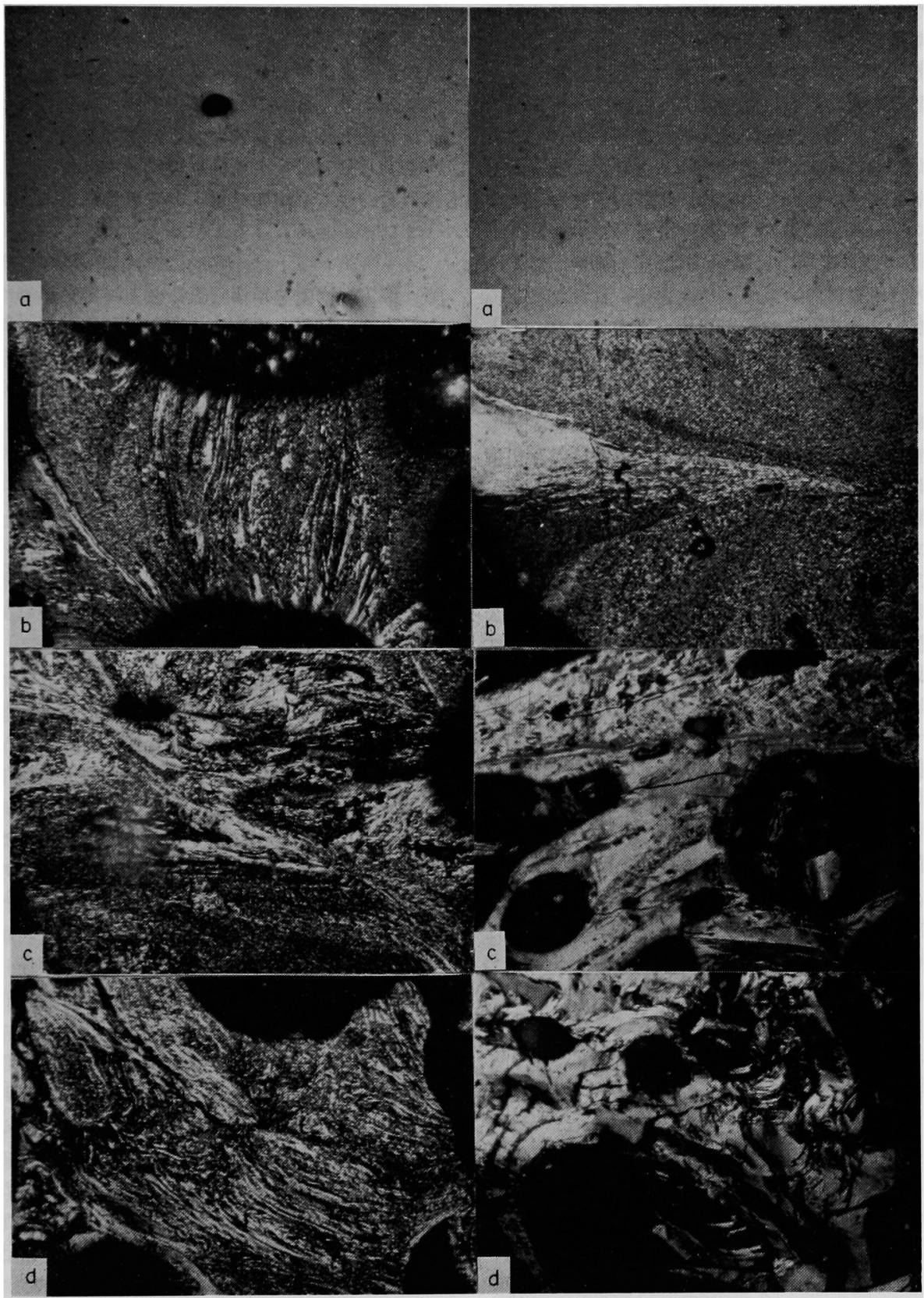

晒川内炭 $(\mathrm{C}=89 \cdot 8 \%, \mathrm{VM}=23 \cdot 8 \%$, daf $)$ (a) $400^{\circ} \mathrm{C}$, (b) $450^{\circ} \mathrm{C}, \quad$ (c) $500^{\circ} \mathrm{C}, \quad$ (d) $900^{\circ} \mathrm{C}$

写真20 乾留の初期段階においてみられるビトリニットの異方性織維状構造（西川内炭, 左側）と 異方性葉片状構造（イットマン炭，右側），(反射偏光 $\times 150 ）$

\section{$2 \cdot 3$ 乾留の初期段階におけるマセラルの変化}

石炭化度を異にする石炭が，乾留の初期段階で軟化溶 融するが，この段階でどのような性状の变化を示すかは 種々の立場から多方面にわたる研究があるが，顕微鏡的
な異方性構造の变化について，とくにピッチ類にみられ る球体の変化と対応させて考察したものは少ない．筆者 らは，数年前よりこの方面の研究を進め，その一部につ いてはすでに報告してきた15)。 
結局，400〜 $900^{\circ} \mathrm{C}$ の温度領域におけるマセラルの挙 動についてみると次のとおりである.

1) ビトリニット・グループ

石炭化度の差異により, 光学的異方性構造に差異が認 められる. 寸なわち, 大平洋炭, 美唄炭のごとき低石炭 化度炭で, 熱的に軟化溶融領域を有しないか，ほとえど 少ないビトリニットでは，上記のいずれの温度でも，異 方性構造はみ、られずにすべて等方性棈造 (Isotropic texture）を示した(写真190左側). 外国炭の場合，たとえ ばニューデール炭に才いても同様である. したがつて, 乾留後に得られるこれらの低石炭化度炭のビトリニット よりのコークスは，いずれも等方性棈造をとることにな る.

これに対して, 三池炭, 夕張炭のごとき石炭化度が中 程度の高流動性粘着炭よりのビトリニットでは, 軟化溶 融領域において異方性啃造が認められるようになる.し かもその特徵としては, $400^{\circ} \mathrm{C}$ 付近の分解がやや始まつ たところではまだ出現せずに，少なくとも $450^{\circ} \mathrm{C}$ 付近 あるいは $410 〜 450^{\circ} \mathrm{C}$ の温度籁围において認められるこ と, きわめて微細な異方性球体と考えられるものの集合 体である粒状モザイク構造 (Fine mosaic texture)を示す

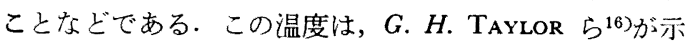
した瀝青炭のビトリニットについての異方性出現温度で ある $460 \sim 470^{\circ} \mathrm{C}$ より，やや低目となつている.この ような粒状モザイク構造はサウザンベル炭, モウラ炭な どにおいても，同様に $450^{\circ} \mathrm{C}$ 付近において認められる. しかもいずれも $900^{\circ} \mathrm{C}$ になつても著しい変化がみられ ない(写真 19 の右側).

さらに石炭化度の高い四川内炭, ミッチェル炭では. $450^{\circ} \mathrm{C}$ 付近において粒状モザイク構造とともに，一部に 脈状異方性を有する䋐維状構造 (Fibrous texture) が認奶

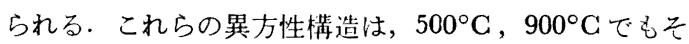
れほど大きな变化はなく, 高々粒状モザイク構造が大き くなるか，一部に方向性を持ち異方性が揃つてくるか， あるいは繊維状楧造がやや発達する程度である（写真20 の左側).

石炭化度がさらに高い低插発分強粘結炭であるイット マン炭のビトリニットでは, やはり $450^{\circ} \mathrm{C}$ 付近で粒状 モザイク構造, 繊維状構造とともに, 特微的な幅の広い 鞠状異方性を有する葉片状構造 (Lea..et texture) が認め られるようになる。これらの䛶造えまた $900^{\circ} \mathrm{C}$ になつ ても若干発達する程度である(写真 20 の右側)。

最終的な敗煙炭では, もちろんこのような暴方性構造 はとらずに，全体的に単一異方性槛造を示すにすきな い.

結局, 石炭化度の差異によつて, 等方性構造, 粒状モ ザイク構造, 纎維状構造および菜片状檴造の 3 種類の異 方性構造, 無煙炭にみられる単一異方性楧造をとること, しかも $450^{\circ} \mathrm{C}$ 付近の乾留の初期段階におりるこれらの
異方性構造生成の挙動が，以後の炭化の進行を左右する ことなどが基本的に知られた。なおこの場合に，加熱速 度による影響があることは当然考えられる。

2) エクジニット・グループ

エクジニットの熱的性質は, 前述したように活性成分 であるビトリニットと同様の性状を示すので, ほぼ同様 の異方性構些が出現するものと思われる.

3) イナーチニット・グループ

イナーチニットは, 熱的に軟化溶融領域を有しないの で，等方性辈造を示すことになる. したがつて，低石炭 化変の非粘結炭, 高石炭化度の無煙炭などと同様に, 等 方性满造を持つた粒子としてコークスの気孔壁中に残存 することになる。

なお，イナーチニットではないが，ビトリニットやエ クジニットが酸化あるいは風化された場合も, 同様に等 方性棈造をとるようになり, 結果的にはイナーチニット とともにコークスの気孔壁中に残存することになる.す なわち, 最近話題になつた輸入原料炭にみられる酸化炭 あるいは風化炭の問題がこれに属する一例である.もち ろえ流動性も減少してくるので，この影響が入つてくる ことも考えられる.

一般に, 有機化合物の炭化, 黑鉛化において, 熱分解 に基づく重縮合が進み，理想的なカーボン構造をとるた めには, まず第 1 に加熱による軟化溶融領域が形成され ること，第 2 に組成的に芳香族縮合環が多環化構造をと りやすい形をとることなどが必要であると考えられる.

このような必要かつ十分条件が，満足された場合には 理想的にはピッチ類に認められたような大小の微小異方 性球体が出現することは，すでに報告してきたところで

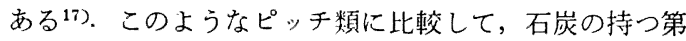
1 の特摧は酸素含有量であるといえる.すなわち，粒状 モザィク構造が認められるようになる領域の石炭は, 酸 素含有量が $5 \%$ 以下である.

石炭の場合，主としてOH基によつて代表される酸素 の存在が一定量以上あると，軟化溶融領域における粘度 が高く, 一部に架橋構造をとりやすい形をとるために, 前述したような異方性構造の差異を生ずるものと考えら れる、また一方では，含酸絜の複素環化合物たとえばシ フェニレンオキサイド, フランのごとき環内酸素の存在 が，芳香族縮合環の再配列による多環化の陪害となる方 向八進むものと考えられる.

一少, 夕張炭が乾留の初期段階において, 光学的に均 一な粒状モザイク構造を示すということは, 夕張炭が構 造的にも組成的にも比較的均質な単位体によつて構成さ れていることを示しており，これが流動性が高くしかも 熱分解過程においてほとえど大きな変化を示さないとい うことともに注目される事実である.

結局, 石炭およびマセラルが， $45^{\circ} \mathrm{C}$ 付近の乾留初期 段階において示す異方性構造の差異および特徵をよく知 
つておくことは, 以後のコークス楧造を基本的に理解 し，コークス性状や強度を予知する上に重要である。す なわち、これを逆に利用することによつて，コークスの 組織構造とそのよつてきたつた履歴を明らかにすること が可能で, その他反応性, コークス強度と親和性につい ての考え方，配合対策，鉃物用コークスでは逆に配合割 合の推定など, 種々のコークス工業に利用しうることを 示している.

\section{2 -4 マセラル分析方法}

コークス強度を推定するための微細組織成分であるマ セラルの分析方法は, 反射率と同㥞に，米国においては ASTM D2799-5th Draft (1969) として検討されてい るが，わが国においてもほぼこれに準じた方法により測 定されている，すなわち，筆者は，コークス化性を考愿 に入れ，また $N$. S AHAPIRO 打よび ASTM の規格案な どを参考として，表 3 のように分類して，これを実施し ている.

要するに, 日本炭に特徵的なマセラルであるデグラデ

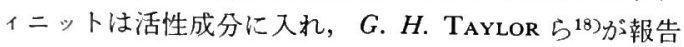
しているようにフジニットーセミフジニットービトリニ ットと移化過程にあるという事実から，偽似ビトリニッ トはセミフジニットの次に位置するという考え方に立つ

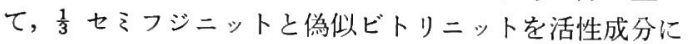

表 3 マセラル分析におけるマセラルの分類 (1970)

A) 活性成分 (Reactives)

1) ビトリニット (Vitrinite)

2) エクジニット(Exinite) $(レ シ ゙ ニ ッ ト$ (Resinite) $\{ク チ ニ ッ$ (Cutinite)

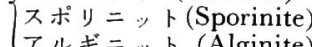

3) デグラディニット (Degradinite)

B) 半不活性成分 (Semi-inerts)

1) セミフジニット (Semi-fusinite)

2) 偽似ビトリット (Pseudo-vitrinite)

C) 不活性成分 (Inerts)

1) フジニット (Fusinite)

2) ミクリニット(Micrinite) $\left\{\begin{array}{l}\text { 微粒状ミクリニット } \\ \text { 粗粒状ミクリニット }\end{array}\right.$

3) スクレロチニット (Sclerotinite)

D) 鉱物質 (Mineral matter)

（注）1）一般に，七ミフシニット，為似ビトリニットは異方性を有す 3.

2) 反射率（共存）は，不活生成分>半不活性成分>活性成分。

3）組䋨は，七ミフシニットはあるが，偽似ビトリニットにはな い.

4）コークス強度推定に祭しては，偽似ビトリニットは全量，セ ミフシニットは $1 / 3$ 老活生成分へ入れる.

5）鉱物曾は，次式により計算し，不活性成分に含める. M. M. $=0.432 \times$ 灰分 $($ 重量\%) $+0.22 \times$ 全イオウ (重量 $\%)$ （ただし，兏分の比重 $=2 \cdot 5$ (ASTM）を使用）
入れて分類する方法をとつている.

本法の概要について示寸と次のとおりである.

マセラル分析には，ドイッの Leitz 社製 Ortholux-

Pol 型反射偏光顕微鏡を使用する.

この際の石炭試料の調留法および研磨法は, ASTMD

2797-70T (1969) に規格化されているが，ほぼこれに準

じて実施している.

光原: $6 \mathrm{~V}, 30 \mathrm{~W}$ タングステン電球

倍率：×250（油浸，対物レンズ×25，対眼レンズメ 10) 対眼レンズ中に 20 ホイントテンプレートを㨂入測 定回数：メカニカルステージを $\mathrm{X}$ 軸，Y軸にそれぞ れ $1.0 \mathrm{~mm}$ あるいは $0.5 \mathrm{~mm}$ 間隔に動かして 300〜 500 点以上測定

結果の表示 : 各マセラルごとの容量\%を0・1\%まで計 算. 鉱物質は Parr の式によつて算出(比重 $2 \cdot 5$ を使用)

以上のようにして求めた石炭中の各マセラルの含有割 合は, 同一石炭化度であつても, それぞれ異なつており その石炭の持つ代表的なビトリニットの性状に対してイ ナーチニットが種々の影響をおよぼしていることの程度 を知りうることになる，すなわち前述したように，縦系 に相当する因子としてマセラルの棈成状態を求めようと したことにほかならない。なお，マセラルの性状の一例 については，前述したとおりである。

\section{5 反射率測定方法}

コークス強度推定のための反射率测定方法は，横糸に 相当する石炭化度を求めようとするものである. 米国に おいてはASTM D2798-70T (1969) として規格化され ているが，わが国においてもほぼこれに準ずる方法で測 定されている.

本法の概要について示すと次のとおりである.

測定装置 (写真 21 参照) は, 前述した偏光顕微鏡に光 電管を用いた Mikroskop-Photometer MPE（最近では MPVを使用）をセットしたものである. また $\lambda=525$ $\mathrm{m} \mu$ の石炭用干涉フイルターを光電管の直前におき，反 射率測定を単色光下で行なうようになつている.これら の機構については $K$. KöTter ${ }^{19)}, W$. Pckhardtら ${ }^{20) か ゙ ~}$

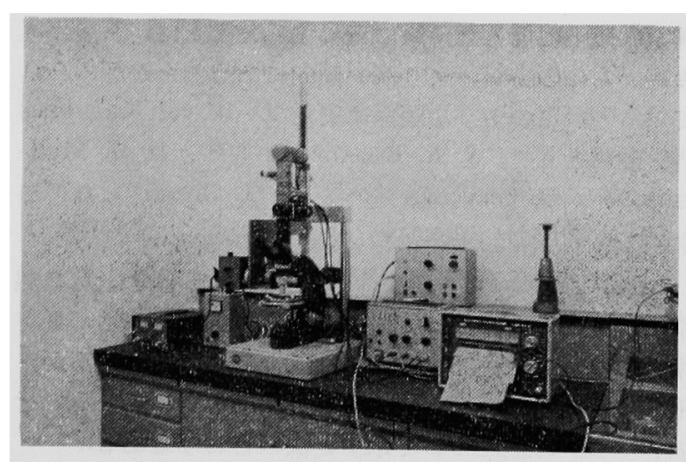

写真21 Ortholux-Pol 型偏光顕微鏡と Mikroskop photometer MPV (E. Leitz 社製) 
詳細に報告している.

光源 : $6 \mathrm{~V}, 30 \mathrm{~W}$ タングステン電球, 電源安定装置が 必要

倍率： $\times 250($ 油浸, 対物レンズ $\times 25$, 対眼レンズ×10) なお ASTM では $\times 600$ (油浸)を使用

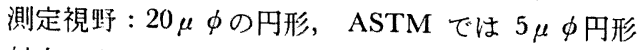

射率スタンダード：約 $9 \%$ 高屈折率特殊ガラス，また 反は閃覀鉛鉱 $(\mathrm{ZnS})$

ASTMでも特殊ガラスを使用

測定回数：ビトリニットの最大反射率を少なくとも 100 点以上測定

最大反射率 $(R o)$ の求方 :

$$
R o(\%)=R s \times J o / J s
$$

$R o=$ 油浸中での求めるビトリニットの最大反射率 $(\%)$

$R s=$ 油浸中での反射率スタンダードの反射率（\%)

$J o=$ 各ビトリニットの最大反射珤における記録計の読 み $(\mathrm{mV})$

$J s=$ 反射率スタンダードの記録計の読み $(\mathrm{mV})$

平均最大反射率 $\left(R_{\text {mean }}\right)$ : それぞれの $R o(\%)$ の算術 平均值 $(\%)$

以上のようにして求めた $R 0 \%$ は, 石炭化度, 石炭そ のものの性状によつて, その頻度曲線が異なる. 通常の 石炭の場合, 反射率の分布は狭い範囲で，たとえば $V_{10}$ を中心としてその両側に $V_{9}, V_{11}$ と正規分布するが，と きには大きく広い範囲にわたつて分布することがある. この極端な例としては，2 種混炭あるいは多種混炭であ る装入炭においてみられる.

それでは横系に相当する反射率と他の性状とが，どの ような関係にあるかについてみてみる。

炭素含有量とビトリニットの反射率は，石炭化度が上 昇するに従つて次第に高くなる傾向がある，この関係は 杉村ら ${ }^{21}$ が図1のように示している.すなわち C 85\% 付近に变移点がなく次第に高くなる曲線を描くという特 徵がある. 一方, ビトリニットを $900^{\circ} \mathrm{C}$ までに熱処理 した場合でも $400^{\circ} \mathrm{C}$ 付近まではほぼ一定であるが, $400^{\circ} \mathrm{C}$ 以上になると急激に上昇するとともに, 石炭化度 の高いものの方が，より高い傾向にあることが認められ ている22).このような関係はまた $D . W$. van KREVELEN 23)を始めとして，S.R. BROADBENT $5^{24), ~ D . ~ G . ~ M U R-~}$ ChISON ${ }^{25)}, D$. Chandra $5^{26)}, T . G . \mathrm{GHOSH}^{27)}$ などに よつても同様の結果が報告されている.

L. G. BENEDICT ${ }^{28)}$ らは，平均反射率と揮発分，発熱 量, ボタン指数について述べているが，このうちボタン 指数のみが $R_{\text {mean }}=1 \cdot 2 \sim 1 \cdot 3$ 付近に極大值があるが， その他はいずれも直線関係にあることを認めている.そ のいくつかの例について示すと次のとおりである.

揮発分 $(d . a . f \%)=60 \cdot 65-25 \cdot 14 \times R_{\text {mean }}(\%), \quad r=$ $-0.96$

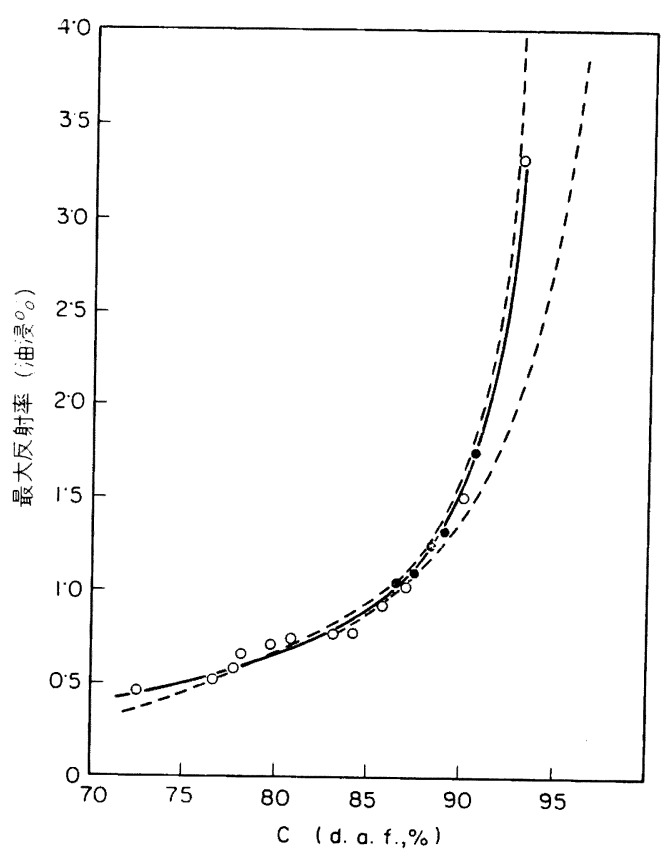

図1 ビトリニットの石炭化度との最大反射率との 関係（杉村ら 1967）

$$
\begin{gathered}
\text { コークス収率 }(\%)=18.03 \times R_{\text {mean }}(\%)+51.64 \\
( \pm 1.33), \quad r=0.96
\end{gathered}
$$

なお，酸化炭の問題にもふれている.すなわち 酸化炭揮発分 $(d . a . f \%)=58.87-24.56 \times R_{\text {mean }}( \pm$ $3 \cdot 65), \quad r=-0 \cdot 88$

となり，若干低下すること，しかも $R_{\operatorname{mean}}=0.8 \%$ 以 下の石炭において変化が著しいことを報告している.

N. SCHAPIRO ら山はた, 最高流動度と反射率との関 係を示しているが，ボタン指数の場合と同様の傾向にあ り, その極大值はやや低い $R o=1 \cdot 0 \sim 1 \cdot 2$ 付近にあるこ とが認められる. わが国においては, 最近筆者ら》が図 2 のように同様の結果を報告している. この場合の極大 值は $K_{\text {mean }}=0.8 \sim 1.0$ 付近に認められる.

一般に, $\mathrm{C}=85 \%$ 付近において粘結性, 最高流動度, ピリジン抽出量など種々の物性の転移点が存在すること から推察すれば， $\mathrm{C}=85 \%$ 付近の反射率は図 1 より Ro $=1 \cdot 0$ 付近に相当するので, ボタン指数の場合やや高目 のように思われるが，この付近から C\% \%に対する反射率 の増加が急激となるので, このような差異があるのは妥 当のように考えられる.

いずれにしても，ビトリニットの反射率と石炭化度お よび他の粘結性に関係のある諸物性が相関連することが 認められよう. $N$. SCHAPIRO らは, コークス強度推定 のために，これらの事実を反射率という因子で代表させ たことになる。

一方, ビトリニット以外の他のマセラルであるエクジ 


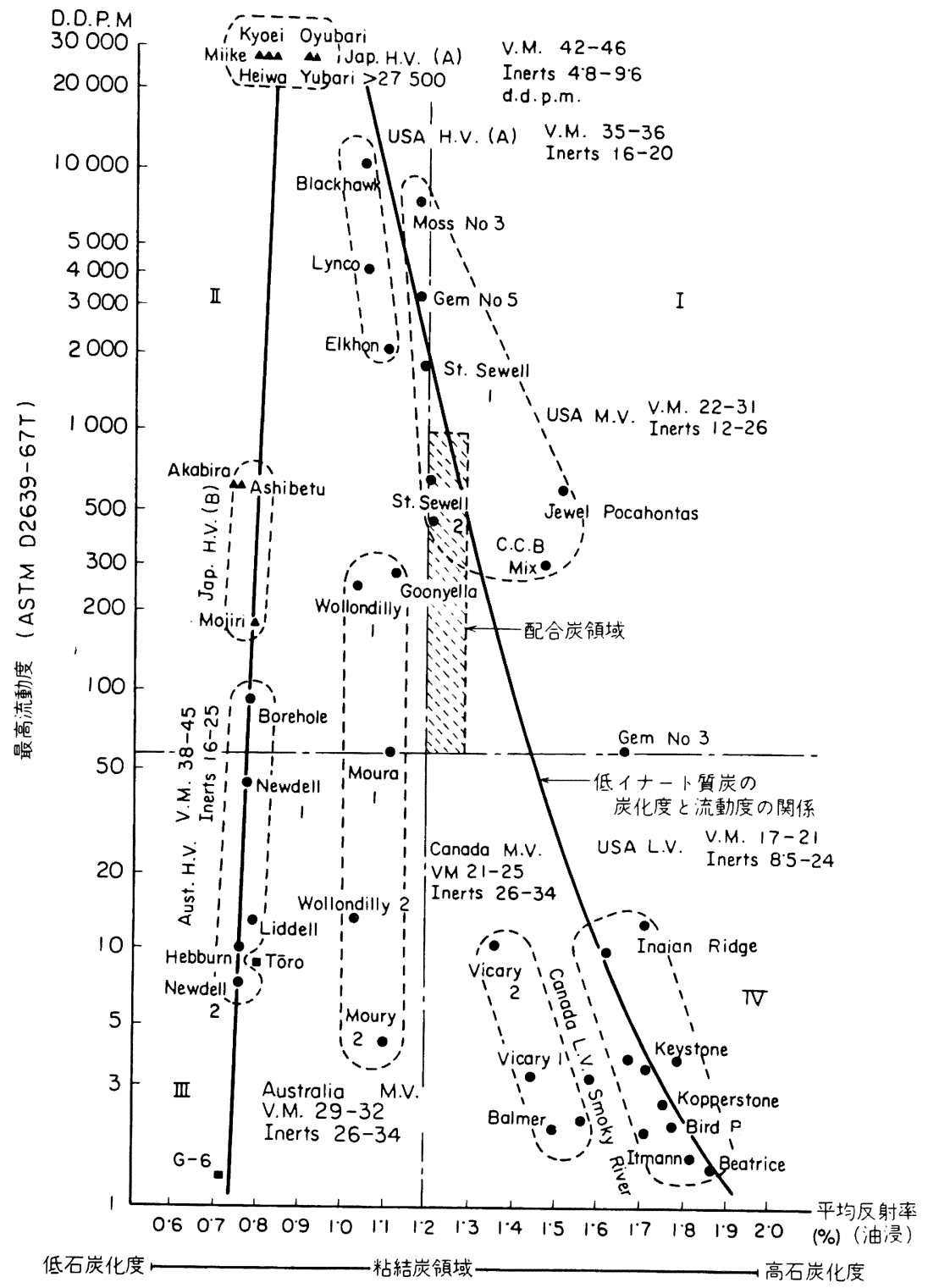

図 2. 原料炭の最宮流動度と反射率の関係（VM：無水無灰べース）

ニットおよびイナーチニットの反射率については， $D$.

$W$. van KREVELEN ら ${ }^{29}$ が, 図 3 のように示している.

すなわち, 石炭化度が上昇するとともに他のマセラルも また，反射率が直線的に増大することが認められる．し かも反射率の高さの程度はイナーチニットがもつとも高 く、イナーチニット>ビトリニット＞エクジニットとな ること,また $\mathrm{C}=91 \%$ 程度でイナーチニット>ビトリ ニット =エクジニットとなり, 反射率の点でもビトリニ ット化が行なわれていることが認められる.

\section{3. 組織学的検討の応用}

コークス工業における，この手法の応用分野は種々考 えられるが，現在すでに実用化されつつあるものについ

て，いくつかの例を述べる.

\section{1 原料岸開発時における予測}

近年, 日本の粗鋼生産量の急激な増加に伴つて, コ一 クス比は漱減しつつあるにもかかわらず原料炭の消費量 もまた急激な增加を示している，国内炭はそのすくれた 配合性のゆえに増産を望まれながら，種々の理由で生産 


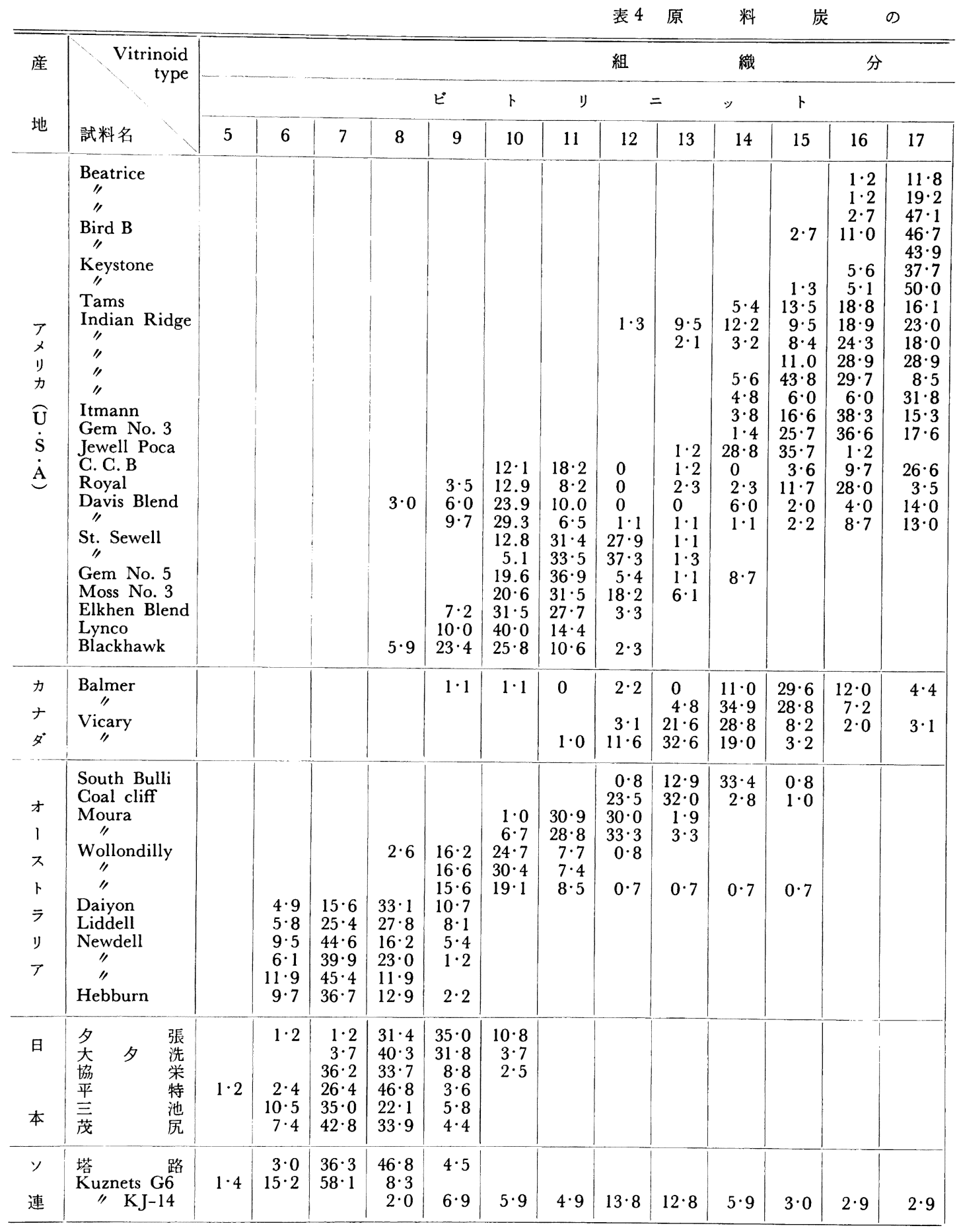




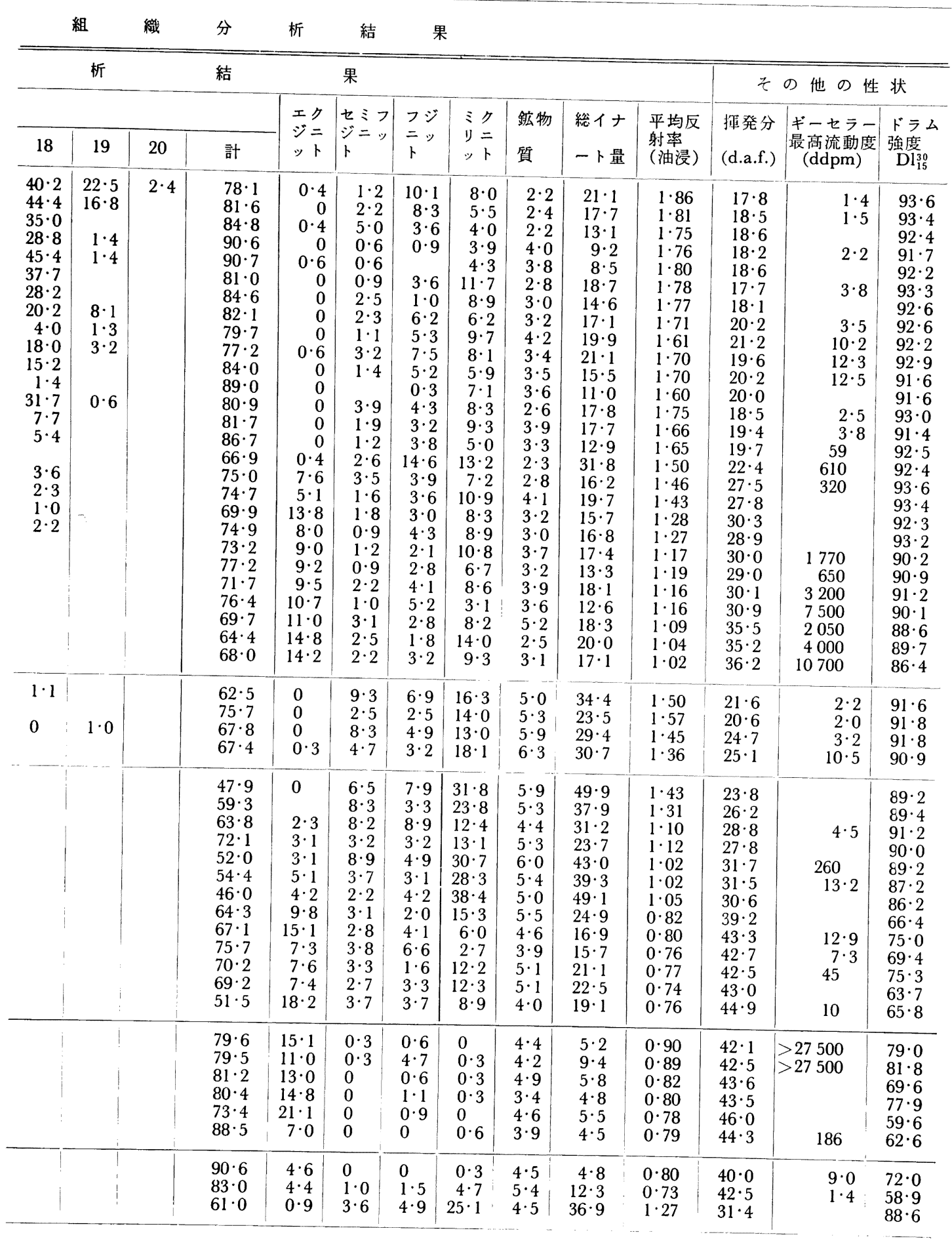




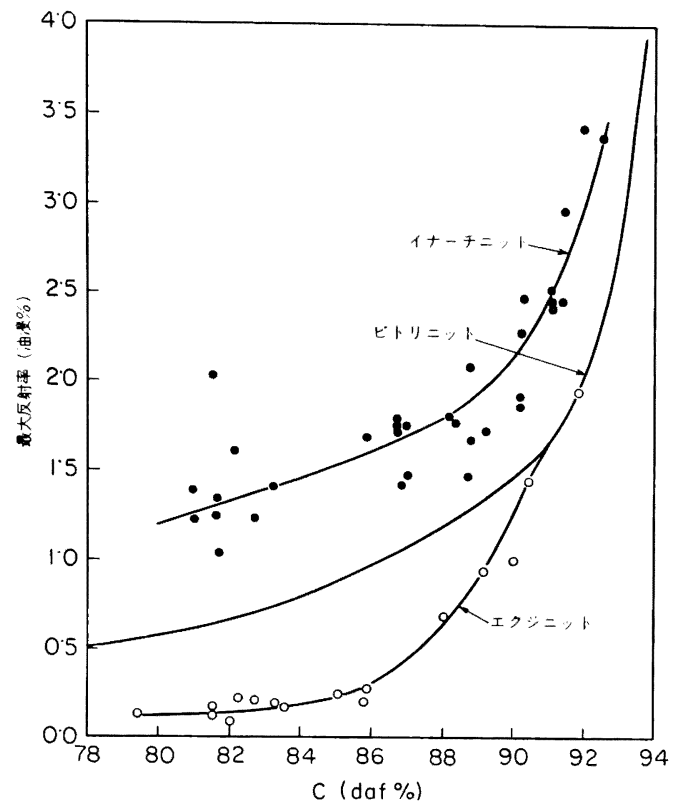

图3.ビトリニットの炭素含有最と各マセラルの最 大反射率との関係 (D. W. van KREVELEN, 1956)

は頭打台となつているから, 今後の原料炭の必要増加分 はすべて海外に仰がなければならない、日本の鉄鋼業の 将来は原料炭資源閒発の速度いか九にかかつているとい つても過言ではないであろう。

資源開発の初期にはボーリングによる炭質の判定が行 なわれるが，コアサンプルは数も多く，かつ通常少量で コークス化試験は行なえないことが多いから，実験室的 な手段でコークス性を判定しなければならない. 組織分 析の手法はこのような場合にもつとも有効であると考え られる。

\section{$3 \cdot 1 \cdot 1$ 石炭化度の推定}

石炭の炭化度の判定には, 彷来種々のパラメタが用い られてきた. 石炭の基礎的な研究の分野では炭素含有量 [C\%(d.a.f.)]が㳂く用いられているが，炭質の分類で は掩発分 [VM\%(d.a.f.)] および発熱量 (m.a.f)*が

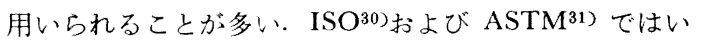
ずれも高炭化度の領域では揮発分で分類し，VM(d.a. f.) $31^{31}$ 及至 $33 \%{ }^{30)}$ 以上の低炭化度の領域では発熱量 (m.a.f.) で分類するシステムを採用している32). 燃料 比を用いることもあるがが，分類の精度は㐫をりよいと はいえない.

これらのパラメタのうち， C\%(d.a.f.) と VM\% (d.a.f.) 閒には高度の相関がみとめられる（ $r=-$ $0 \cdot 978)^{34)}$ ので, この両者の炭化度判別力はほぼ同程度と

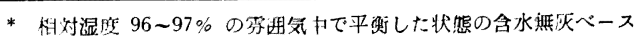

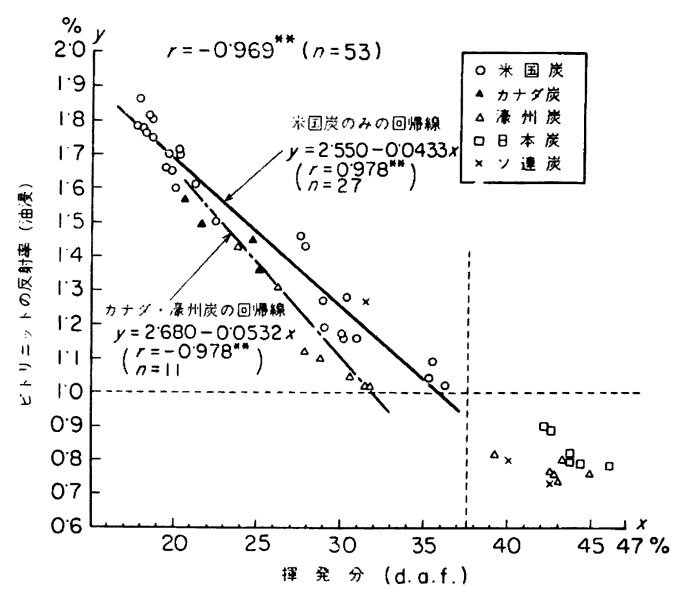

図 4. 揮発分 $(\mathrm{d}, \mathrm{a}, \mathrm{f})$ と反射率（ビトリニット） の関係

考えられるが，いずれもイテート質**量の影響をうける ために，敛密には正確な石炭化度を示さない欠点がある。 図 4 は表 4 の VM(d.a.f) と反射率（ $\bar{R} o ）$ の值をプロ ットしたものであるが, $\bar{R} 0>1$ 以上の 41 銘柄につい て，米国炭 27 銘柄と，力ナダ . 豪州炭 14 銘柄に層別 すると，明らかに回帰線が異なつていることがわかる. このことはカナダ・豪州炭グループのイナート質量が米 国炭グループ (8.5〜26\%) よりも著しく多い(26〜34\%) ために, 同一炭化度ならば米国炭よりもVM (d.a.f) が低く出ることを意味している、いいかえると，米国炭 とカナダ・豪州炭の VM(d.a.f.) が同一ならば，一般 に米国炭の方が炭化度が進んでいるものと考えなければ ならないこのようにVM を基準として炭化度を判定 するときには，イナート質量を考虑しないと䛊りをおか 寸危険がある. 反射率測定值の方は，イナート部をさけ て，ビトリニット部のみの測定をするので，このような 危険性は少ない，資源開発時に実際に生じた一例をつぎ に示す.

Goonyella 炭 (硋州・クイーンスランド) 中層のコア サンプルによる兏質調査の例

的 15 呎のコアサンプルを色調により, 上部, 中部, 下部に 3 分割し，それぞれの性状を測定したところ，表 5 に示すデータを得た

VM(d.a.f.) の值で判断する限り，炭層の上部に進む につれて炭化度が進んでいるか，あるいは風化を受けて いるかのいずれかであろうと考えられ，ギ一セラ一流動 度の值もこの判断をうらづけるものであるから，従来な らばそのような判断を下したかもしれない。しかし，組 織分析の結果によれば全く逆の判断が下される.

すなわち

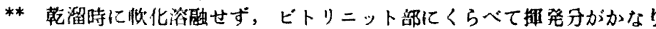
低い。 
表 5 Goonyella 炭（中層）の性状

\begin{tabular}{|c|c|c|c|c|c|c|}
\hline 試 & 料 & VM(d. a.f.) & 最高流動度（ddpm） & $\bar{R}_{0}$ & 活性グループ＼cjkstart計（\%) & イナート質計 $(\%)$ \\
\hline $\begin{array}{l}\text { 上 } \\
\text { 中 } \\
\text { 下 }\end{array}$ & $\begin{array}{l}\text { 部 } \\
\text { 部 } \\
\text { 部 }\end{array}$ & $\begin{array}{l}26 \cdot 88 \\
27 \cdot 87 \\
29 \cdot 55\end{array}$ & $\begin{array}{r}286 \\
1630 \\
11000\end{array}$ & $\begin{array}{l}1 \cdot 13_{2} \\
1 \cdot 13_{6} \\
1 \cdot 17_{5}\end{array}$ & $\begin{array}{l}60 \cdot 2 \\
65 \cdot 0 \\
79 \cdot 4\end{array}$ & $\begin{array}{l}39 \cdot 8 \\
35 \cdot 0 \\
22 \cdot 6\end{array}$ \\
\hline
\end{tabular}

表 6 各 Vitrinoid ごとの Strength Index ${ }^{35)}$

\begin{tabular}{l|l|l|l|l|l|l|l|l|l|l|l|l|l|l|l|l|l|l|l}
\hline Vitrinoid type & 3 & 4 & 5 & 6 & 7 & 8 & 9 & 10 & 11 & 12 & 13 & 14 & 15 & 16 & 17 & 18 & 19 & 20 & 21 \\
\hline
\end{tabular}

Reflectance in oil (\%) $0 \cdot 390 \cdot 490 \cdot 590 \cdot 690 \cdot 790 \cdot 890 \cdot 991 \cdot 091 \cdot 191 \cdot 291 \cdot 391 \cdot 491 \cdot 5911 \cdot 691 \cdot 791 \cdot 891 \cdot 992 \cdot 062 \cdot 19$

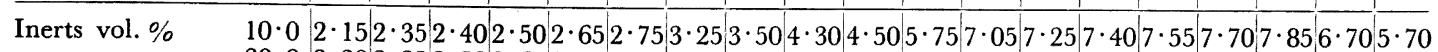
$20 \cdot 02 \cdot 202 \cdot 352 \cdot 502 \cdot 652 \cdot 802 \cdot 903 \cdot 503 \cdot 753 \cdot 504 \cdot 755 \cdot 957 \cdot 007 \cdot 157 \cdot 307 \cdot 457 \cdot 607 \cdot 756 \cdot 355 \cdot 00$

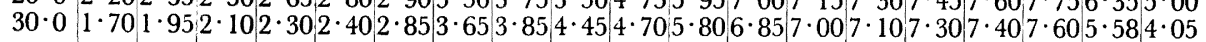

表 7 Optimum inerts ratio $^{35}$ )

\begin{tabular}{|c|c|c|c|c|c|c|c|c|c|c|c|c|c|c|c|c|c|c|c|}
\hline Vitrinoid type & 3 & 4 & 5 & 6 & 7 & 8 & 9 & 10 & 11 & 12 & 13 & 14 & 15 & 16 & 17 & 18 & 19 & 20 & 21 \\
\hline ratio & $4 \cdot 4$ & $4 \cdot 0$ & $3 \cdot 7$ & $3 \cdot 3$ & $3 \cdot 0$ & $2 \cdot 8$ & $2 \cdot 5$ & $|2 \cdot 5|$ & 2.9 & 3.5 & $4.5 \mid$ & 6.0 & 8.0 & $10 \cdot 9$ & $13 \cdot 6$ & 16 & & $20 \cdot 7$ & 23.0 \\
\hline
\end{tabular}

a ）マセラル分析のさいの観察では，上部のほうがイ ナート質を多く含有しており, ビトリニット部には，と くに風化によるクラックはみとめられなかつた.

b ）ビトリニット部の反射率はわずかながら下部に進 むほど高く, 下部の石炭化度が進えでいることを示して いる.

したがって，上部の VM が低く，かつ流動度が低い 理由は風化あるいは石炭化度の影響ではなく, イナート 質量が多いことによるものと結論することができる.

これは一例にすきないが，このように少量のコアサン プルのみについて炭質を判定しなければならないときに は, 組織分析の手法はきわめて有効であるものと考元ら れる。

\section{$3 \cdot 1 \cdot 2$ 単味コークス強度 $\left(D I_{15}^{30}\right)$ の推定}

反射率の測定值とマセラル分析のデータからタンブラ 一強度を推定するための Consolidation Coal Corp.の 数值表 ${ }^{35}$ ）(その1 部を表 6,7 に示す）を使用して，ド ラム強度を推定するグラフ（図 5 ）の作成を試みた. 手 順はつぎのとおり,

a) Strength Index をもとめる

各試料炭ごとに実測した反射率およびマセラル分析值 （表4）をつぎの手順によつて処理する.

手順 1） 100 点の反射率測定值を表 6 によつて各Vitrinoid type に分類し，それぞれのビトリニット\% $x_{i}$ をもとめる.

手順 2) 各 Vitrinoid type ごとに, 全イナート量に 対応する係数 (a.b…, s) を表 6 からもとめ, これに上

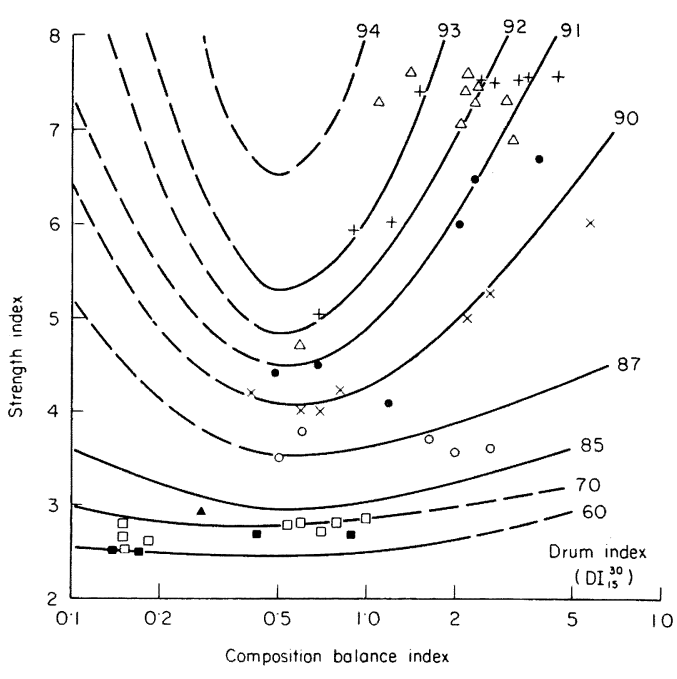

図 5 Composition balance index, strength index と実測 $D I{ }_{15}^{30}$ の関係

記\%を積算する.

手順 3) 次式によつて算出する.

Strength Index $=\frac{a x_{3}+b x_{4}+\cdots+n x i+\cdots+s x_{21}}{\Sigma x_{i}}$

ただし， $x_{i}$ : Vitrinoid type $i$ におけるビトリニット\% $\Sigma x_{i}:$ 全ビトリニット\%，乙れは 100-(イナー ト\%) に等しい.

たとえばある試料のイナート量が $20 \%$ であつたと 


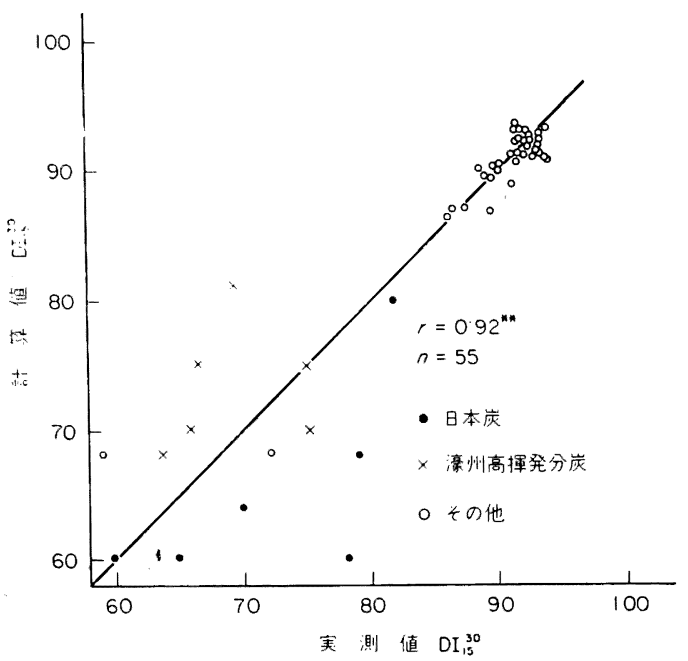

図 6 組織分析による単味コークス強度の推定值と 実測値の関係

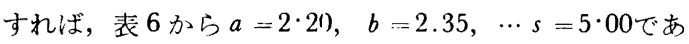
るから, Strength Index はつぎのようにしてもとめら れる.

$$
\text { Strength Index }=\frac{2 \cdot 20 x_{3}+2.35 x_{4}+\cdots+5 \cdot 00 x_{21}}{100-20}
$$

b) Composition Balance Index(C.B.I.)をもとめる

手順 1) 各 Vitrinoid typeごとに， $x_{i}$ をそれでれ表 7 の Optimum Inerts ratio で割つて集計する.

乎順 2) 次式によつて算出する.

$$
\text { C.B.I. }=\frac{100-\Sigma x_{i}}{x_{3} / 4 \cdot 4+x \cdot / 4 \cdot 0+\cdots+x_{21} / 23 \cdot 0}
$$

c) Strength Index を縦軸に，C.B.I.を横柚にとり 各試料炭ごとの実測ドラム指数（表 4) の等高線を引く と図 5 が得られる.

このようにして得たグシフによる $D I_{15}^{30}$ の推定值と実 測值の関倸は図 6 に示すとおりで, 高度の相関はみとめ られる $(r=0.92 * *)$ ものの, $D I_{15}^{30}<80$ の領域では推 定の精度がわるい.とくに高流動度の（イナートの少な い）国内炭は実測值が推定值より高く, 低流動度の（イ ナートの多い）豪州高拌発分炭ではこの逆の傾向を示し ている.このことは，タンブラ一強度推定用に作られた 表 6，7 の係数が，ドラム強度推定用には適当でない 上くに低反射率領域に打けるイナート質の効果を過少評 俩している一ことを意味している、いいかえると，タン ブラ一強度とドラム強度に対するイナート量の寄与の程 度が異なつているために図6のような偏差が生じたもの と考えられる。

いずれにせよ，現在の段階では，まだこのような手法 による単味コークスの $D I_{15}^{30}$ の推測はあまり正確とはい えないが，少なくをも日本では単味コークスを治金用に 使用することはあり得ないので, この程度の予測でもか
なり有効といえるでろあう。

$3 \cdot 1 \cdot 3$ 配合度として使用するためのメ引ットの推定 表 4 に示した行㮔のデータのうち，ビトリニットの反 射婆とギーセラ一最高流動度をプロットすると図 2 のよ うになる.イナート量の少ない米国炭, 国内炭, 豪州弱 粘炭のグループを結ぶと実線で示したような関係曲線が 得られ, 反射率 $0 \cdot 9 \sim 1 \cdot 0$ 付近で流動度が最大となり, 反射率がこれより高くても低くても流動度は急激に低下 与ることがわかる. カナダ炭, 豪州中揮発分炭のグルー プはイナート量が多い $(26 \sim 34 \%)$ ために同一反射率の 他のグループより流動度が低く, 上記の関係曲線より下 方に外れる.

一方高炉の使用に適する高強度のコークスを得るため には, 配合炭として適度の石炭化度と流動性を必要とす るが，その範井は経験上，図の斜線で囲まれた領域でな ければならない. 石炭化度がこれ以下になるとコークス としての固さを不足し, 流動度が高すぎるとクラックが 多くなり，低すぎると粒子間の接着が不良となる. した がつて, 配合炭として必要と考光られる流動度の下限お よび平均反射率の下限（約 1.2）を基準として原料炭を 4 群に分類することができよう.すなわち図 2 の第 I, IV 象限に属する石炭は配合炭の平均石炭化度を維持する たわに絶対必要であり, 現在のところ米国炭, カナダ炭 以外にこのグループに属するものはきわめて少ない，第 I, II 象限に属する石炭は平均流動度を維持するために 是非必要であり，とくに国内炭はすぐれた接着剤として の効果をるつている. 将来国内炭の比率が減少する場合 には, このグループの石炭の重要性はさらに増加するで

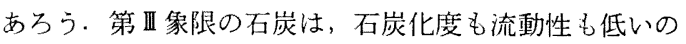
で, 配合時の炭素源としての意味しかない。たとえば高 州弱粘炭の使用量を增加するためには, 配合炭領域の対 照の位置にある米国中揮発分炭を増配合するか，あるい は米国低揮発分炭と国内炭の増配合を必要とすることに なる・

以上のような検討方法によれば，資源調査時のボーリ ングによる少量のコアサンプルのみによつて，その石炭 を将来配合炭の一部として使用するときの価值を予測す ることが可能でむろう.

\section{$3 \cdot 2$ 入船時における品質変動の検討}

榆入原料炭の銘柄数, 数量は年々急増しているが, こ れに伴つて品質上のトラブルもまた増加している. これ らのトラブルの主なものは

(a) 選炭不完全によるボタの混入

(b) 風化炭の混入

(c) 混合銘柄の混合比の変動

などであるが，（b)，（c）については化学分析では判 別がむずかしく，コークス化試験により異常を発見され る例が多い，已し本船入港前，あるいは入船直後に少量 の（もちろん代表試料であることが必要であるが）試料 


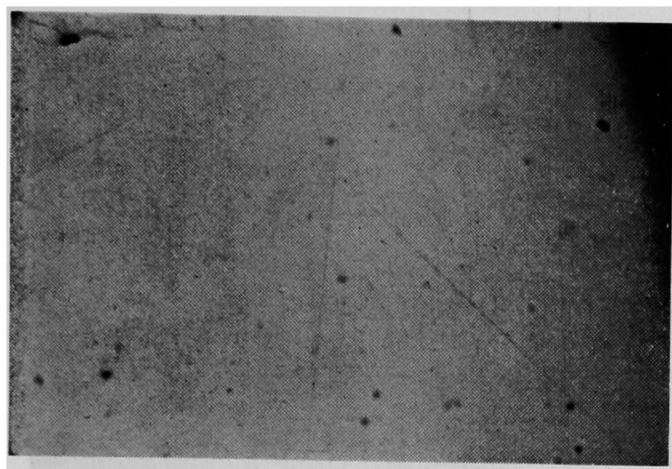

写真22 風化していない石炭のビトリニット部

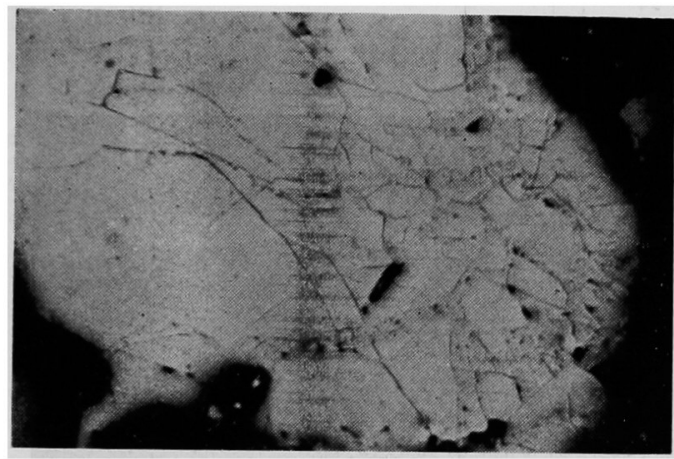

写真23 風化した石炭のピトリニット部

風化による微細な亀裂がみとめられる

を入手でき机芯，組織分析による(b)，（c）のチェック は可能である.

\section{$3 \cdot 2 \cdot 1$ 風化炭の判別}

マセラル分析のさい, もし試料炭が風化していれば, ビトリニット部に風化に起因する微細なクラックが観測 される(写真 22,23 参照). さらに風化が進行すると, 試 料面に酸化被㬴が観測されるこ・ともある。これらの観察 は定性的なものて，風化の程度を定量することはむずか しいが，風化の進行は一般に流動性の低下を伴うので， これらの情報を総合すれば，比較的迅速に風化によるト ラブルを現場に予告することは可能であろう。

\section{$3 \cdot 2 \cdot 2$ 混合銘柄に打ける混合比の推定}

とくに米国中掩発分炭などのように，低插発分炭と高 揮発分炭をある比率で配合している場合, あるいは揮発 分は同程度でも炭層の異なる数種の銘柄を混合している ような場合には，同一銘柄名であつても入船ごとにコー クス化性が大幅に変動する危険性が大きく，これはVM のみではチェックできない.

この場合も 3.2 と同様入船前あるいは入船直後化試 料が入丁できれば組織分析による迅速チェックが可能で ある。

当社に入着した D.B. 炭の実例をつぎに示す.

1963 年の入荷炭 2 船分の反射実測値のヒストグラム
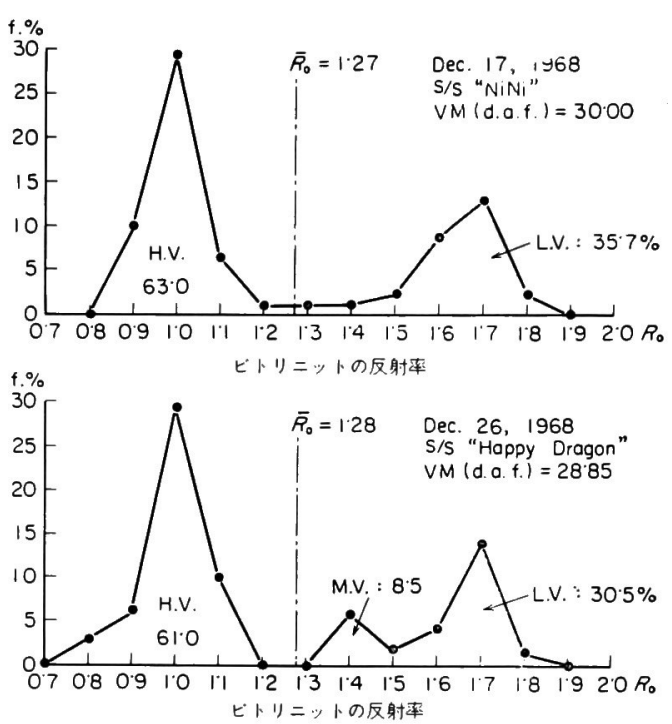

図 7 D.B. 炭（1968 入船分）の反射率 測定值のヒストグラム
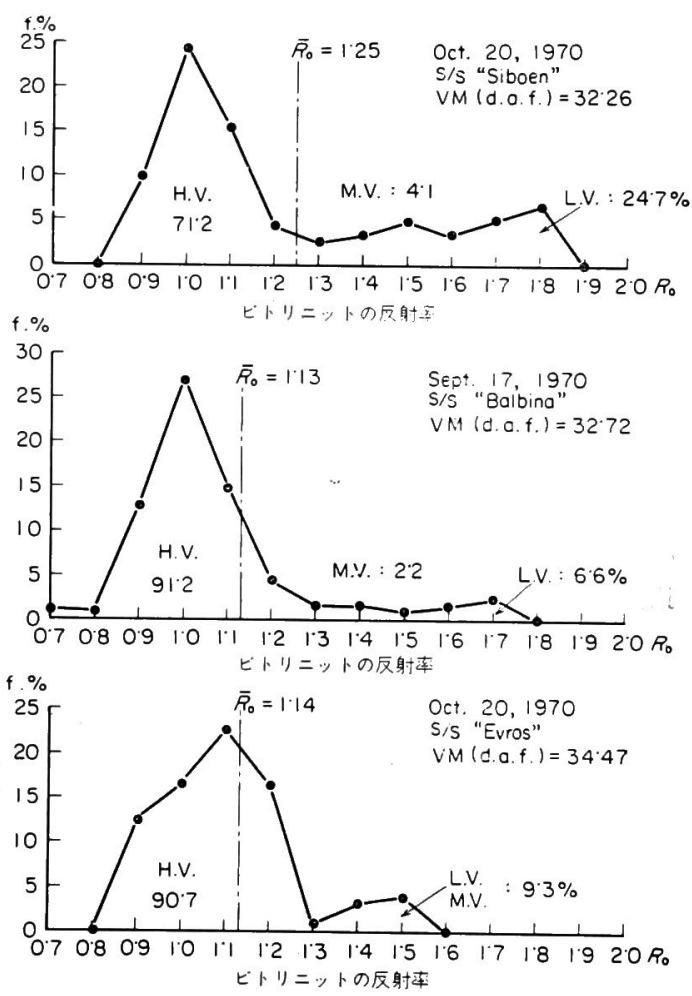

図8 D.B. 炭 (1970 入船分) の反射率 測定值のヒストグラム

は図 7 に示すとおりで, $\bar{R}_{0}=1 \cdot 27 \sim 1 \cdot 28$ であり, $R_{0} \geq$ $1 \cdot 5$ の低揮発分炭は約 $30 \sim 36 \% ， R_{0} \leq 1 \cdot 3$ の高揮発分炭 
は 61〜63\% 程度今まれていたと考えられる*.これに対 し 1970 年の入荷炭の 3 船分のヒストグラムは図 8 に示 すとおりで，低揮発分炭の配合比は5〜25\% 程度に低 下していることがわかる．これに伴い高挥発分炭の配含 比は約 90〜71\%ににで上昇しているので， $\bar{R} o$ も1.13 〜1·25に低下している.

以上はややや極端な例で，この堭合はVMも $2 \%$ 以上 増加しているから, 分析值のみでもある程度の判别はで きるが，混合炭の配合比を推定することは，組織分析以 外の手段では不可能であろう.

\section{$3 \cdot 3$ 各種の研究に対する寄与}

石炭, コークスに関する唖々の基礎研究あるいは開発 研究の過程で, 石炭, コークスの組織を観察し, 分析す ることによりきわめて有効な情報が得られることはいう までもない. とくに将来, 米国炭ならびに国内炭の配合 比率低下に伴う配合炭のコークス化性低下が予期され, しかも，コークス品質に対する要求が現在以上に均酷に なることは既定の事定であるから，このような研究手段 に対する期待は今後亡すをす增大するものと思われる. コークス組織の観繁が有効である一例をつぎに示す.

Balmer 炭の微粉砕により $D I_{15}^{30}$ が向上した例: 写具 24 は Balmer 炭を通常の粒度（3 mm 以下 $80 \%$ ) で コークス化**したときのコークス組織であるか，イナ一 ト部とビトリニット部が偏在している. 写真25は同じ石 炭をスラリー榆送のために微粉砕したのちコークス化** したものであるが，イナートとビトリニットが均等に分 散融合していることがわかる. コータスの組織としては 後者が望ましいことは明らかであり，DI $I_{15}^{30}$ は 84.6 か ら 91.5 に向上している.

\section{4. ととがき}

以上, 石炭の組織学的な検䖞と, その応用について述 ベなが，このような抹法が研究の手段以外の目的で日本 のコークス技術者閒でとり上げられるようになつたのは 比較的最近のことで，まだ広く普及しているとはいえな い. 現在, この方法がもつとも有力であり，かつ比較的 広く用いられているのは, 原料炭資源開発時におけるボ ーリングコアサンプルのような，ごく少量の試料からコ 一クス化性を推定したいという場合で，日常配合管理な どのような，実際のコークス炉操業に活用寸るには，今 後なお検討を要する問題（サンプリング誤差, 測定の再 現精度など）が数多く残されているように思われる. 本 資料が今後の検討に何らかの参考亡なれば幸いである.

本資料の執筆にあたり，種々ご教授，ご援助を賜わつ た石炭技術研究所杉村秀彦氏（現三井コークス KK）に 深く感謝いたします。

* 低捕発分炭と高抑発开炭のイナート量の差を考覤していないので, 竡密な推定とはいえないか，混合比の変動の推定としては总味が ある.

** Fuels Research Centre, Ottawa の 1000 lb 捣による.

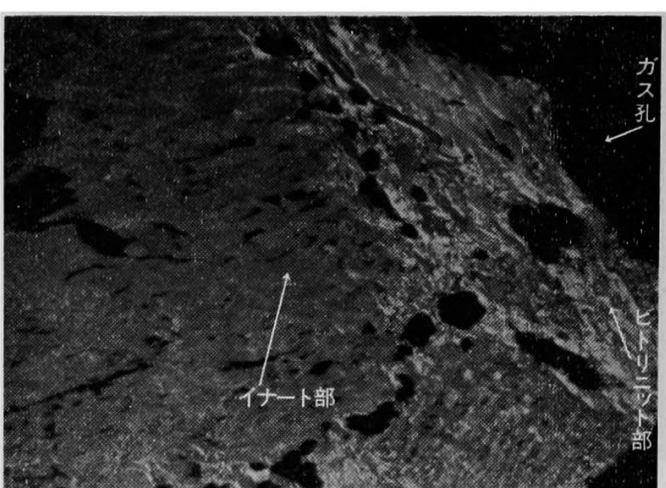

军真24 Balmer 炭を通常粒度 (-3 mm. 80\%) でュ ークス化したもの $\left(D I_{15}^{30}=84 \cdot 6\right)$

イナートとビトリニットが偏在している.

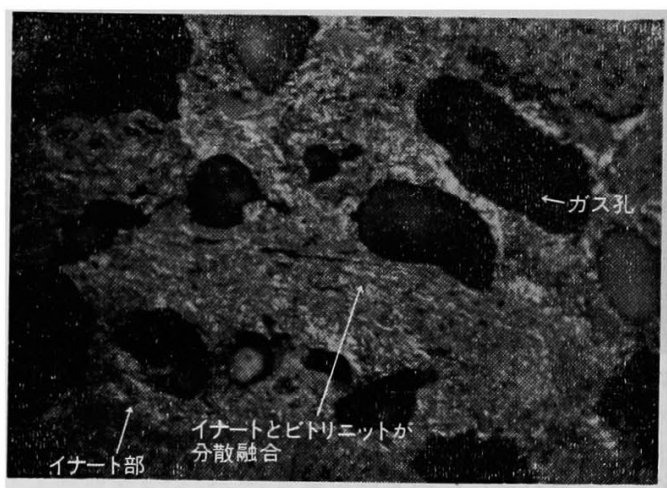

写真25 Balmer 炭を微粉砟 $(-47 \mu 18 \cdot 5 \%)$ したの ちコークス化したもの $\left(D I_{15}^{30}=91 \cdot 5\right)$ イナートとビトリニットがよく融合し, 均質 な構造となつている.

\section{交献}

I) I. I. Ammosov, I. V. Eremin, S.I. Sukhenko, and L.S. Oshurkova: Koks i Khimina, (1957) 12 , p. 9

2 ) $N$. Schapi, $R . J$. Gray, and $G . R$. Euser: "Blast Furnace, Coke Oven and Raw Materials Conference" Coal, (1961), p. 89

3 ) $N$. Schapiro, et al.: J. Inst Fuel, 37(1964), p. 234

4) H. R. Brown, G. H. TAYler, and A. C. Cook: Fuel, 42(1963), p. 43

5 ) 高橋良平, 永井利明: 燃協誌, 48(1969), p. 928

6) L. G. Benedict, R. R. Thompson, and $R$. $O$. Wenger: Blast Furn. Steel Pl., No 3 (1968), p. 217

7 ) 奥山泰男, 宮津隆, 杉村秀彦, 熊谷光照: 燃協誌, 49(1970), p. 736

8 ) International Handbook of Coal Petrography, International Committee for Coal Petrology, (1963) 
9) 石炭組織研究会, 燃協誌, 37(1958), p. 597

10) 木村英雄，コークスサーキュラー, 19(1970), p. 88

11) C. Kröger: Brenn. Chem., 38(1957), p. 147

12) B. Alpern: Congr. Chim. Ind., 2(1954), p. 9

13) $H$. Hoffmann, et al.: Brenn. Chem., 35 (1954), p. 202, 236, 269, 298

14) $R$. $R$. Thоmpson and $J . J$. Shigo: III L. G. Benedict and R. P. Aikman, Blast Furn. and Steel Pl., 54(1966), p. 817

15) 木村, 真田, 菅原, 古田, 本田, 杉村, 熊谷: 燃協誌, 49(1970), p. 752

$H$. Honda, $H$. Kimura, $Y$. Sanada, $S$. SugaWARA, and $T$. Furuta: Carbon, 8(1970), p. 181

杉村秀彦, 熊谷光照, 木村英雄, 本田英昌: 燃協 誌, 48(1969), p.920

16) G. H. TAYlor: Fuel, $40(1961)$, p. 465 ; J. D. Brooks and G. H. Taylor: Carbon, 3(1965), p. 185: Chemistry and Physics of Carbon, 4 (1968), p. 243

17) 本田, 木村, 真田, 菅原, 古田, 武田：学振 117 委資料，117-101-A1，117-101-A2，117-102-A3 (1968), 117-103-A4, 117-106-A2(1969)

18) G. $H$. TAYloR, et al.: Fuel, $46(1967)$, p. 431

19) $K$. Kötter: Brenn. Chem., 41 (1960), p. 263
20) $W$. Pckhardt and $K . L$. Robock: Brenn. Chem., 46(1965), p. 44

21）杉村秀彦，紫波正史，燃協㘶，46(1967), p. 911

22）杉村秀彦，熊谷光照，木村英雄，本田英昌：燃協 誌, 48(1969), p. 920

23) D. $W$. van Krevelen: Coal, 343(1961)

24) $S$. $R$. Broadbent and $A$. $J$. Shaw: Fuel, 34 (1955), p. 385

25) D. G. Murchison: Bulletin of Inst.of Mining and Metallurgy, 73(1964), p. 479

26) D. Chandra and $R$. L. Bond: Internat Comm. Coal Petrology Proc., 2(1956), p. 47

27) T. G. Grosh: Econs. Geology, 63(1968), p. 182

28) L. G. Benedict and $W$. F. Berry: 55th Coal Science, 55(1966), p. 643

29) $D . W$. van Krevelen and $J$. Schuyer: Coal Science, (1957), p. 235

30) ISO/TC27, 143E (1953)

31) ASTM: D 388-66

32）似息次蚛，桜井康三，小関消，小林治二：燃協誌， $49(1970)$, p. 881

33) JIS M 1002

34）宮津隆：コークス技術年報，コークスシリーズ， 9,26 (1959)

35) $G . R$. Friedrich (Consolidation Coal Corp.) 私信 